\title{
WestVirginiaUniversity
}

THE RESEARCH REPOSITORY @ WVU

Graduate Theses, Dissertations, and Problem Reports

2005

\section{A West Virginia family in World War II}

Miles B. Berger

West Virginia University

Follow this and additional works at: https://researchrepository.wvu.edu/etd

\section{Recommended Citation}

Berger, Miles B., "A West Virginia family in World War II" (2005). Graduate Theses, Dissertations, and Problem Reports. 751.

https://researchrepository.wvu.edu/etd/751

This Thesis is protected by copyright and/or related rights. It has been brought to you by the The Research Repository @ WVU with permission from the rights-holder(s). You are free to use this Thesis in any way that is permitted by the copyright and related rights legislation that applies to your use. For other uses you must obtain permission from the rights-holder(s) directly, unless additional rights are indicated by a Creative Commons license in the record and/ or on the work itself. This Thesis has been accepted for inclusion in WVU Graduate Theses, Dissertations, and Problem Reports collection by an authorized administrator of The Research Repository @ WVU. For more information, please contact researchrepository@mail.wvu.edu. 
A West Virginia Family in World War II

Miles B. Berger

Thesis submitted to the Eberly College of Arts and Sciences at West Virginia University in partial fulfillment of the requirements for the degree of

Master of Arts in History

Elizabeth Fones-Wolf, Ph.D., Chair Robert Lewis, Ph.D.

Jason Parker, Ph.D.

Department of History

Morgantown, West Virginia

2005 


\title{
ABSTRACT \\ A West Virginia Family in World War II
}

\author{
Miles B. Berger
}

As an analysis and examination of the letters of two West Virginia residents written during each resident's service in World War II, this thesis compares the wartime experiences of a brother and sister against secondary and primary source literature covering World War II and the Women’s Army Auxiliary Corps/Women’s Army Corps. The experiences of these two soldiers are told through an interpretation of their letters home and an examination of the training experiences of women and men in World War II. In addition, the first main section of the thesis, Chapter Two, is devoted to an overview and analysis of the Women's Army Corps. The following two chapters are a summary of the letters of First Lieutenant Anna Marie Fisher and Staff Sergeant E. Steve Fisher, respectively. 


\section{Table of Contents}

Chapter One: Introduction..................................1

Chapter Two: The WAAC $\ldots \ldots \ldots \ldots \ldots \ldots \ldots \ldots \ldots \ldots \ldots \ldots \ldots \ldots . . .7$

Chapter Three: First Lieutenant Anna Marie Fisher............35

Chapter Four: Staff Sergeant E. Steve Fisher..................68

Chapter Five: Conclusion..................................85

Bibliography and Works Cited.............................88 


\section{Chapter One: Introduction}

The United States found itself engaged in numerous military conflicts and wars throughout the twentieth century. None of these wars has been written about, researched, and studied more so than World War II; in addition, no war during the twentieth century caused more American deaths than World War II. The effect of "The Great War" on the American psyche and on the American people has been a subject of intense analysis and debate in the sixty years since the end of hostilities during the summer of 1945 . This war truly defined a generation of Americans and shifted the norms of certain aspects of American life, including typically established gender conventions. Also, the war created a generation of heroes for the American people. The actions of individual soldiers and support personnel, the dedication of multiple groups of young men and women who in many cases were barely old enough to vote, and the resounding finality of a clear victory for America and the Allied forces created an aura around the World War II veterans that had previously been solely reserved for veterans of the American Civil War.

Researching, analyzing, and studying the actions, writings, emotions, and feelings of these individual soldiers is crucial in creating a working understanding and appreciation of World War II and its effects upon America and the soldiers themselves.

This thesis uses the letters written by two veterans of World War II, one who died in service while in Italy during the final months of the war in Europe, another who lived through the conflict and returned home in June 1945. First Lieutenant Anna Marie Fisher

and Staff Sergeant E. Steve Fisher each served in the European theater. Brother and sister, the letters of the two soldiers demonstrate the way in which a family coped with the pressures of war and the way in which a war changes both individuals and the greater 
American culture. Topics in these letters include many things that are to be expected from young men and women living in an exciting time and serving their nation overseas. Dating and "love" experiences are popular topics in many of the letters, especially those written by Anna Marie; these letters also suggest that the female soldiers serving in the Women’s Army Auxiliary Corps (WAAC) were breaking new ground in the areas of dating and that these experiences contributed to the shift in American gender conventions that peaked twenty years or so after the end of World War II. In addition to this, interest in home and questions about others who are simultaneously serving in the war are prevalent in the letters. Also, many of the areas which the two soldiers were serving were filled with historical sites and beautiful areas, especially those in which First Lieutenant Fisher served. These letters to their mother, Stella Fisher, tell of seeing these areas of Italy, North Africa, France, and England; pictures are included with some of the documents. These pictures are of such things as Anna Marie riding camels in North Africa and jovially standing in front of Italian buildings with fellow soldiers and WAACs.

These letters are one important source of information about the participants in World War II. Letters were sent home both to family and friends, though the vast majority of letters preserved in this case were sent to the mother of the two service members. Letters, coupled with official military documents, are able to give the researcher a valuable insight into the actions and thoughts of individual soldiers. For many soldiers, the letter was an escape from the reality of actually fighting in combat during the war; to other soldiers, it was a way to share their lives with their loved ones and family members. These letters and pictures are especially intriguing to me, as First 
Lieutenant Fisher is my great-aunt and E. Steve Fisher is my grandfather. The letters and stories of these two American soldiers, contrasted with and analyzed alongside of the overall experience of soldiers during World War II, give an insight into military life during the war.

The Women’s Army Auxiliary Corps (the Auxiliary label was dropped early in the war), or WAAC, offered women the chance to serve the United States in World War II. In previous wars, the role of women had been strictly limited to nursing and a small number of supplemental roles. While the WAAC did not offer women the opportunities that women are currently offered in the military, the service of these women marked an important landmark in both women's history and military history. As historian Karen Anderson has observed, "because of its duration and the extent of civilian participation it fostered, no war in American history has had as profound an effect on American society and American women. World War II marked a temporary retreat from prevailing notions of women's capabilities and proper roles."1 Through programs such as the WAAC and the WAVES (Women Accepted for Volunteer Emergency Service), as well as other military organizations formed during the war, women were able to directly contribute to the war effort.

This service in the WAAC and in the other female military organizations changed these women and changed the role of women both in the military and in American society. Women adopted the roles of men both on the homefront (in factory and warindustry jobs) and in the theaters of battle. This service and the work of these women showed the general American public that women were more capable of performing tasks

\footnotetext{
${ }^{1}$ Karen Anderson, Wartime Women: Sex Roles, Family Relations, and the Status of Women During World War II (Westport, Connecticut: Greenwood Press, 1981), 4.
} 
that had been historically reserved for males. Service in the military also opened up opportunities for women and helped to bring about increased rights and responsibilities for women in general. These changes together led to a shift in previously held gender conventions and altered the role of women in society and in the military. Women not only found themselves in jobs that previously had been held solely by males, but also found themselves experiencing new norms of dating while in military service. For instance, First Lieutenant Fisher discusses dating married men in a few of her letters, an action that was not held in high regard in society but was accepted on the battlefront and in military camps. Also, historian Leisa Meyer discusses the aspects of lesbianism that made their way into the WAAC and the other military organizations, indicating an additional shift in typical gender conventions.

The inclusion of the WAAC and of females into military service meant that for the first time in American history excluding nurses in World War I, men and women would be alongside each other overseas during wartime. Service in the military was also a transforming experience for many young men, including Staff Sergeant Fisher. Many of these men, including Fisher, who was just 18, entered the service at a young age. Indeed, historian Paul Fussell contends that a "notable feature" of World War II was the "youth of most who fought in it." ${ }^{2}$ These men, like all military servicemen, experienced basic training and the rigors of war. Staff Sergeant Fisher, who served as a ball-turret gunner on the B-17 "Flying Fortress" aircraft, was forced to deal with one of the most difficult jobs in the war, one with the highest non-infantry casualty rate, yet, emerged from the conflict unscathed and improved as a man. While some who experienced

\footnotetext{
${ }^{2}$ Paul Fussell, Wartime: Understanding and Behavior in the Second World War (New York: Oxford University Press, 1989), 52.
} 
combat bore the scars of war for the rest of their lives, for other soldiers, like Fisher, the war was a positive experience that contributed to further success in life. There was a sense among many of these men that the efforts of American G.I.’s helped to save the world from tyranny and oppression while simultaneously building individual character and ending dictatorial oppression. Historian Lee Kennett notes that one marked characteristic of American G.I.'s was that they took pride in the fact that they worked together, as a unit, in order to accomplish tasks. ${ }^{3}$ The men serving in the war truly did have these feelings of pride and accomplishment, feelings which were shared by many of the women as well.

This thesis will explore the experience of both men and women during World War II, utilizing the letters of two siblings who served simultaneously in the European theater and using other primary and secondary sources as well. The letters and these other sources will help to show the basic mentality of individual soldiers serving overseas in the war and the effect that such service had on the families of these soldiers. In addition, this thesis will also examine the role of the Women's Army Auxiliary Corps in the war, especially focusing on the instances which Anna Marie's letters contradict what is contained in the historical literature surrounding the WAAC. The thesis will include three chapters and a conclusion. One chapter each will be devoted to First Lieutenant Fisher and Staff Sergeant Fisher. Also, one chapter will focus on the WAAC, incorporating Anna Marie’s letters to a lesser extent than secondary sources, recounting the history of the organization, its formation, its recruitment efforts, and its legacy. Few historians and few graduate students have the opportunity to write about family in a

\footnotetext{
${ }^{3}$ Lee Kennett, G.I.: The American Soldier in World War II (Norman, Oklahoma: University of Oklahoma Press, 1997), 224.
} 
historical context and it is this student's hope that this effort is both intriguing and useful as a source of historical knowledge. 


\section{Chapter Two: The WAAC}

The Women’s Army Auxiliary Corps was especially important in World War II. A WAAC recruitment postcard from 1942, shortly following the attacks of December 7, 1941 upon Pearl Harbor that brought the United States into World War II, states that the WAAC “offers women an opportunity to help win the war by performing non-combatant duties so men can fight."1 Many women, over a quarter of a million in all, would defend the United States during the war. A small percentage of these women, met the same fate as Anna Marie, passing away in the service of their nation. Over four hundred military women lost their lives fighting in World War II, including over 100 nurses and 38 members of one of the WAAC's sister groups, the WASP's. ${ }^{2}$ Overall, about 250 WAACs were killed in the line of service. More women would serve in the WAAC than in any other of the women's military organizations. The formation of the WAAC in May 1942 marked a shifting point for women, one that shifted their normal roles in American society.

Before World War II, women had served only in limited roles during wartime. Women had performed nursing duties as well as minimal clerical and support work during previous wars such as the American Civil War and World War I. During World War II, women became a regular part of the military and the opportunities for women, so severely limited in respect to military service in the past, opened up for the first time in American history. The instigation for all of this increased opportunity can be attributed, at least in part, to the actions of Congresswoman Edith Nourse Rogers of Massachusetts.

\footnotetext{
${ }^{1}$ WAAC Recruitment Postcard. 1942.

${ }^{2}$ www.undelete.org/military/lives.html.
} 
As Emily Yellin notes, “In spring [May] of 1941, U.S. Representative Edith Nourse Rogers of Massachusetts made it known she was about to introduce a bill to establish a woman's branch of the U.S. Army...she had wanted the bill to give women full military status, with the same pension, disability protection, and rights as the men, but realized she could not secure that.”3 Rogers, who had replaced her deceased husband in Congress following his death more than a decade earlier, knew that her bill would be a controversial one. During the 1920s and 1930s, much change had been taking place surrounding gender relations in America. The right to vote was established for women in 1920, women challenged social conventions during the era of the "flappers" in the 1920s, and in the 1930s, during the Great Depression, many women found work while their husbands faced layoffs. Rogers was a progressive woman and wanted to push for even more changes in the American landscape, this time, in the military.

Representative Rogers felt that her bill had enough support to pass Congress. Part of the reason that she believed the bill would pass was that there was strong sentimental support backing female participation in the war. While the bill would not actually pass until May 1942, Rogers recognized that “American women wish to defend their country in the present emergency and also permanently against war. So do women everywhere...Our present defense looks to the future for inspiration and sustenance. There are few sane men in the world who want war to continue as part of the historical pattern. There are no women.” ${ }^{4}$ This comment may allude to a reason why women hoped to enter the war: possibly some women felt as if they were the only sane voice that

\footnotetext{
${ }^{3}$ Emily Yellin, Our Mother's War: American Women at Home and at the Front During World War II (New York: Free Press, 2004), 113.

${ }^{4}$ Margaret Culkin Banning, "Women for Defense," in American Women in a World at War: Contemporary Accounts from World War II, eds. Judy Barrett Litoff and David C. Smith (Wilmington, Delaware: Scholarly Resources, Inc., 1997), 11.
} 
could intervene in a violent and bloody conflict. While not directly stated, this reasoning is supported by historians such as Margaret Culkin Banning and Leisa Meyer, women who have written about the service of women in the war. Nevertheless, a few outspoken women did not share this same support for the war and for American intervention into the war. These women organized themselves in anti-interventionist groups and protested in and around the areas surrounding Washington, D.C. These protests continued in other cities, mostly large, yet, despite all of these concerted efforts, the movement to stay out of the war held very little water, especially after the attacks on Pearl Harbor in December 1941. Women who did support women's involvement in the war far outnumbered those who did not and those who participated in these protests that went on most frequently around the nation's capital. Historian Margaret Paton-Walsh notes that one supporter of the effort stated "we are a group of women who have enlisted in the FIGHT FOR FREEDOM. We want it known that the hysterical women who have been demonstrating in Washington do not speak for us.”5

General George Marshall and other important figures in the military pushed hard for the formation and establishment of a military grouping that would incorporate women. Officers and leaders of the military realized that women could fill many of the tasks that would free up men for more direct service. In addition, the strength of women's desire to serve and their clear ability to help win the war were strong reasons that men such as General Marshall supported the inclusion of women into the military. In early February 1942, General Marshall named a thirty-seven year old lawyer, Oveta Culp Hobby, the wife of the former governor of Texas, William P. Hobby, to the position of

\footnotetext{
${ }^{5}$ Margaret Paton-Walsh, Our War Too: American Women Against the Axis (Lawrence, Kansas: The University Press of Kansas, 2002), 181.
} 
director of the WAAC. The fact that General Marshall named Mrs. Hobby to this position before the bill to form the organization she would direct was even passed is indicative of the support that these men held for the establishment of the WAAC. Women around the country, many men around the country, politicians from pretty much all areas excepting the South, and important men in the military all pushed for passage of the bill that had been introduced by Representative Rogers. Though Congressional opposition did exist, mainly from those who felt that women should not serve overseas in theater during wartime, the bill passed Congress. In early May 1942, after some vocal opposition but with resounding support, the bill passed the House of Representatives by a vote of 249-86. On May 14, 1942, the Senate voted, in a much closer vote of 38-27, to pass the bill to create the WAAC. ${ }^{6}$ President Roosevelt then signed the bill into existence the following day. ${ }^{7}$

The passage of the bill did touch off some debate among the American people; most of the criticism for the bill's passage came from Southern Democrats and other conservatives who felt that the role of women was being disturbed by the bill. Many who were either uncomfortable with change or who felt that such a bill was unnecessary expressed their opinions in various forms. “When women entered 'men's trades' and the armed forces in the Second World War they knew it had been done before, but like the previous generation, they still experienced the amazing feeling of breaking new ground. It was exhilarating for women to take up 'men’s work,' although it provoked fear in men

\footnotetext{
${ }^{6}$ Judith Bellafaire, “The Women’s Army Corps: A Commemoration of World War II Service,” contained on and found in official military record at www.army.mil/cmh-pg/brochures/wac/wac.htm.

${ }^{7}$ Yellin, Our Mother's War, 114.
} 


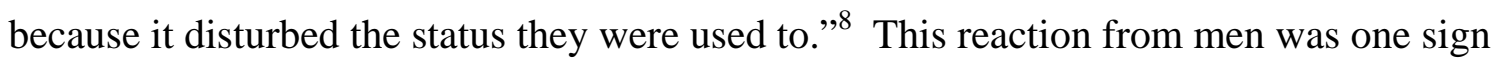
that a shift in gender conventions was beginning to occur and that the reception for the WAACs may not be entirely accepting. However, much more support than opposition existed for the bill and that support was wide-ranging among both men and women. The Army had established an organization of women that, while not fully incorporated into the Army (the Auxiliary label meant that women could not be full members of the Army nor could they serve in combat), would still directly contribute to the war effort in a more hands-on manner than the more familiar and popularized "Rosie the Riveter."

While certain differences existed between the types of service embodied in the WAAC and the jobs that Rosie the Riveter performed, women rushed to fill both of these positions. WAAC recruiters were able to quickly fill their recruitment goals and in many cases exceeded their goals in large numbers. Seeing this success, other military organizations also wanted to utilize the services of women while not giving the women full military benefits and status. Yellin writes that "women had entered the U.S. Army as soldiers for the first time in American history. And once that beachhead was secured, it was only a matter of months before four other women's military branches were established. In July 1942, the Navy established the WAVES. Then, in November 1942, the Coast Guard formed the SPAR (Semper Paratus, Always Ready). In February 1943, the female Marines came into being, with no catchy acronym. And in August 1943, the WASP (Women Airforce Service Pilots) was formed.” ${ }^{\circ}$ By the end of the war, 140,000 women had served in the WAAC or WAC; 100,000 women had served in the WAVES; 13,000 women had served in SPAR; 23,000 in the Marines; and 1,000 in the WASP.

\footnotetext{
${ }^{8}$ Gail Braybon and Penny Summerfield, eds., Out of the Cage: Women's Experiences in Two World Wars (London: Pandora Press, 1987), 4-5.

${ }^{9}$ Yellin, Our Mother's War, 115.
} 
Following the initial passage of the bills and the formation of the WAAC itself, recruitment efforts began in full force. Historian Doris Weatherford, in her book History of Women in America: American Women and World War II, writes that "Women were so eager to sign up that many went without breakfast. Bosses waited in vain for secretaries, nurses arrived late and breathless at hospitals, dishes went unwashed and floors unswept...in one day, over 13,000 women had applied for just 450 announced slots as officer candidates." ${ }^{10}$ Another historian, Ann Allen, in the journal Military Affairs, writes of the way in which the popular media of the time covered the WAAC and of the initial positioning of recruitment efforts. "All media sources gave ample coverage to the WAAC in its initial months of operation. In fact, the media could be credited as the major sources of information that caused recruiting stations to be swamped with applications and inquiries from women interested in changing mufti for khaki." ${ }^{\text {11 }}$ To promote the recruiting effort, magazines and newspapers portrayed military women as attractive and feminine, yet still contributing strongly to the war effort. Advertisements and articles in magazines such as Life, Time, and the Saturday Evening Post showed attractive military women and, for the most part, uplifted women and encouraged the female war effort. Anna Marie, who had collected newspaper articles that followed Hitler’s campaign through Europe during the late 1930s and kept them in a scrapbook, was one woman who did not need these flashy advertisements to convince her to sign up for the WAAC, however, these recruiting brochures and magazines were crucial in getting women to join the military. An advertisement attempting to recruit WAVES, for

\footnotetext{
${ }^{10}$ Doris Weatherford, History of Women in America: American Women and World War II (New York: Facts on File, Inc., 1990), 33.

${ }^{11}$ Ann Allen, “The News Media and the Women’s Army Auxiliary Corps: Protagonists for a Cause," Military Affairs 50 (April 1986): 77.
} 
instance, stated that "the girls in the WAVES are real American women - the kind who love parties and pretty clothes, and who are good at cooking and sewing too. They're very feminine, and proud of it." ${ }^{\text {12 }}$

While the Army personnel in charge of recruitment information may have exaggerated some of the characteristics of the women enrolling in the WAAC in order to increase interest, their efforts show that worry existed early on about whether or not the average American woman would feel comfortable signing up for military service. Early on, detractors of the WAAC had questioned the femininity of the women volunteering for service. It was the job of the recruiters and of the WAAC leaders to dispel these rumors. Luckily for Director Culp and the U.S. military, many women, including Anna Marie, were not detracted from joining the military.

There was no doubt that, at least to a certain extent, life in the military was different from everyday civilian life. The hope among military leaders was that women would not have a more difficult time adjusting to service than men. This mentality was expressed during the meetings at which initial training and setup of the WAAC training camps was discussed. Many women (and men) found themselves attempting to duly adjust to military life and "an important part of the adjustment was learning to mock the military's ways while yet scrupulously complying; learning the value of an ironic smile. Women adopted the mentality of girls at Scout Camp - a cheerful, getting-on-with-thejob compliance that still left room for shared griping and occasional mischief."13

This desire to leave home and experience something new attracted some women to the WAAC. Anna Marie mentioned in numerous letters, both while in the United

\footnotetext{
${ }^{12}$ Maureen Honey, Creating Rosie the Riveter: Class, Gender, and Propaganda During World War II (Amherst, Massachusetts: The University of Massachusetts Press, 1984), 114.

${ }^{13}$ Weatherford, History of Women in America, 56.
} 
States and while overseas, how exciting it was to be able to do some of the things that she was doing that never previously had been available for women to do. In addition, she mentions that without the WAAC, she never would have been able to visit many of the places that she was able to visit while in service. The WAAC opened up new worlds for these women; that was just another way in which the shift in gender conventions was occurring. Also, Anna Marie and many other women felt a strong antagonism toward Germany and the other Axis powers. Most of the women who served in the war believed wholeheartedly in what they were doing. One woman stated that "we feel deeply and acutely the threat which the Axis presents to our families, our homes, and the fundamental principles of civilized society... we are convinced that the Nazi machine must be outlawed by the civilized world...we are determined to do our share to safeguard our future." ${ }^{14}$ Other women enlisted because they wanted to go overseas; many of the women who served in the WAAC, in fact almost all, had never been overseas previous to World War II. In the June 8, 1942 issue of Life magazine, the column writer wrote that "On May 27, for the first time in history, the U.S. Army began general recruiting of women. The response was terrific...there were college girls and career women, shop girls and stenographers, housewives and widows. Before the day ended, 13, 208 had applied.”15 This incredibly strong response was due in large part to the overwhelming sentiment that these women felt to contribute to the war effort.

Again, the military hoped to show that women would be able to perform their military and clerical responsibilities and still maintain their femininity, something that most women wanted to maintain. The women of the WAAC and the military

\footnotetext{
${ }^{14}$ Paton-Walsh, Our War Too, 181.

15 “WAAC: U.S. Women Troop to Enlist in Army’s First All-Female Force,” Life, 8 June 1942, 26.
} 
policymakers differed, however, on their views of what women should wear. John Costello writes that “The U.S. army's determination to make no concessions to 'feminine vanity and civilian frippery’ soon resulted in a wrangle over women's uniforms. Director Hobby argued for a stylish martial cut patterned on uniforms of regular soldiers. Army brass, determined to put as much distance as possible between men and women, argued for blue uniforms." ${ }^{\prime 16}$ The fight over the maintenance of femininity among the different groups lay at the heart of the debate not only over what women would wear, but, more importantly, what the role of these women would be. Leisa Meyer writes that "The conviction that women, because of their femininity, would not perform well in a military environment was evident in media coverage of the auxiliary in its first year of existence which focused on the humorous consequences of a feminine auxiliary. The exaggerated definitions of femininity framing these editorials included a lack of intelligence, an ability to perform simple tasks or to endure any kind of hardship." ${ }^{\text {17 }}$ The women set out to prove their critics wrong and while the criticism that surrounded the WAAC did not entirely subside throughout the war, the balance of service and femininity was maintained as much as possible.

Few American women wanted to give up their style, looks, and basic nature for the military; however, they really wanted to serve and advertisers reinforced these ideas. Maureen Honey writes of some of these examples of strategic marketing. "Camel cigarettes ran a series on women in the armed forces that showed women in fatigues in one part of the ad and off duty in evening gowns with officers in another part. Canada

\footnotetext{
${ }^{16}$ John Costello, Virtue Under Fire: How World War II Changed Our Social and Sexual Attitudes (Boston: Little, Brown, and Company, 1985), 43.

${ }^{17}$ Leisa Meyer, Creating G.I. Jane: Sexuality and Power in the Women's Army Corps During World War II (New York: Columbia University Press, 1996), 26.
} 
Dry [ginger ale] made a similar attempt to maintain feminine identities of servicewomen...A Whitman's ad used a similar technique, by showing a beautiful WAC receiving the traditional gift a suitor brings to his sweetheart - a box of chocolates.”"18 This early rush of WAAC advertising and the early rush of WAACs volunteering for service tapered off a bit after the first couple of months of the enlistment period. For the year 1942, the WAAC did not fulfill its entire Congressional quota of $150,000^{19}$, however, this is due in part to the fact that the quota was increased to such a high number. Some blame this failure on the media as well, including Ann Allen. She writes that "the causes of decreasing public interest in the WAAC, in the final analysis, could not be blamed on insufficient media coverage. To the contrary, there had been ample publicity. The problem lay in the focus and content of news stories and the media practices of attempting to capture public attention through misleading headlines and article captions. ${ }^{20}$

Similar to the "yellow journalism” that predominated during the SpanishAmerican War forty-five years earlier, outlandish claims by certain journalists led to distortions of the truth in some areas of the news media. In addition, some of the ad campaigns were counter-productive. Ann Allen writes that "simultaneous with the drop in recruitment and public interest, in the early months of 1943 a stigma had slowly begun to attach itself to military women, especially Waacs. The ground swell was not felt until about May when slanderous remarks generated by disgruntled servicemen were reinforced by some newspaper and magazine hints of moral indiscretion among the

\footnotetext{
${ }^{18}$ Honey, Creating Rosie the Riveter, 114.

${ }^{19}$ Blake Clark, "Ladies of the Army," Readers Digest 42, May 1943, 85.

${ }^{20}$ Ann Allen, “The News Media and the Women’s Army Auxiliary Corps,” Military Affairs 50, April 1986, 82.
} 
Waacs.”21 Some of these newspaper stories were prompted by servicemen, some of who were uncomfortable with female military service, started rumors that the women were prostitutes and that they were promiscuous. While this may have been true in isolated incidents, these rumors were for the most part completely false. Doris Weatherford writes that "the relationship that developed between men and women in the ranks was much like that of siblings. There was resentment, rivalry, and conflict, but there was also support, understanding, and pride. Enlisted women and men soon came to see each other as people. It was a relationship that was often new to both sexes.”22

Women, like their male military brethren, had to go through basic training and initial processing before being fully integrated into the military. For many women who would attend these training camps that were spread around the United States, it was their first time away from home for any extended length of time. Doris Weatherford writes that "the very first WAACs were sent for initial training to Fort Des Moines, Iowa. Here their presence personified historical change, for Fort Des Moines was a cavalry post that was no longer needed in modern warfare...that first WAAC class - the 440 officer candidates chosen from those 13,000+ applicants on the first day of recruiting - was truly an exceptional group.”²3 Blake Clark writes in a May 1943 Readers Digest article that “The recruit's first days at Fort Des Moines begin in bewilderment. She usually arrives with 40 or 50 others. As they pile off the train they present a motley civilian picture of slacks and mink coats, high heels and low."24 Following the opening of Fort Des Moines, which graduated the first class of WAAC officer candidates, a WAAC training center

\footnotetext{
${ }^{21}$ Allen, "The News Media and the WAAC," 81.

${ }^{22}$ Weatherford, American Women and World War II, 100.

${ }^{23}$ Weatherford, History of Women in America, 51.

${ }^{24}$ Clark, "Ladies of the Army,” 86.
} 
was opened in the more accessible location of Daytona Beach, Florida. In addition to these two training centers, WAAC centers were also opened in Georgia at Fort Oglethorpe and in Massachusetts at Fort Devens. Each of these locations had advantages and disadvantages and housing was one of the biggest concerns, especially early on at the training centers in Iowa and Daytona Beach. "Classrooms and barracks had no distinction in the total-training atmosphere of boot camp. Shined shoes and latrine inspections were just as vital as good grades in class. However, despite the advantages of Fort Des Moines as a setting, there soon developed a critical shortage of barrack space...Daytona Beach had worse housing problems; women lived the first few days in a tent city."25

The average day in any one of the various training camps was quite difficult, though the women did find time during breaks, “dead” times, and on the weekends to go out and to see the areas surrounding the bases where they were stationed for training. Some believe that the experience was, overall, educational for women and others think that it was simply an effort made on the part of the male-controlled military to restrict and indoctrinate women. In truth it was most likely a combination of both. Boot camp was difficult both for women and for men, especially those not used to a rigorous schedule. Women had strict supervision while in training camp and on a typical day WAACs rose before dawn, marched in unison to breakfast, then cleaned and straightened their barracks. Following cleaning, the women attended classes and engaged in close-order drills and physical education training, then, more food, followed by lights out at 9:00 and a bed check at 11:00. ${ }^{26}$ Learning army protocol and the structure and organization of the

\footnotetext{
${ }^{25}$ Weatherford, History of Women in America, 52.

${ }^{26}$ Weatherford, History of Women in America, 51.
} 
various parts of the armed forces was an important part of the training, as was building friendships and unison among the women in the camps. Exercises that tested the strength, both mentally and physically, as well as the endurance, attitudes, and abilities of the women were stressed in the camps as well. These experiences were under a slightly stricter eye than were the men's experiences in basic training, due in large part to the desire on the part of the Army to make sure that the WAACs stayed in line and were not negatively publicized.

Anna Marie served her training duty in all of the four WAAC training camps except Fort Des Moines, though that was where her graduation ceremony was held. In a letter home that was written on December 26, 1942, while stationed in Daytona Beach, Florida, Anna Marie provided a detailed description of her typical day as an officer candidate working in the Florida winter sun. She wrote to her brother, who was not yet in the military, "Steve, here is my daily schedule you wanted. Now you know I’m busy. 6:15 - Reveille

7:00 - Breakfast

8:25-9:10 - Interior Guard

9:20-10:05 - Hygiene

10:15-11:00 - Military Courtesy

11:10-11:55 - Care of Rooms

12-1:30 - Lunch

1:30-2:10 - Care and maintenance of uniforms 2:20-3:05 - Army Ranks 
3:15-4:00 - Calisthenics”27

Anna Marie continues in her letter to write that “we haven’t really started drilling yet but have a week of it after our basic, which lasts four weeks. Lights go out at nine and bedcheck is at 11:00, except on weekends. Gods! What a healthy life.”28 These early days in the WAAC training camps were a new experience for all involved and they set the tone that the WAAC would follow for the rest of the war. Many women, including Anna Marie, endured mental and physical exertion in an effort to become officers in the United States military.

The women of the WAAC and of the military had various types of work to complete and many different kinds of training to fulfill before they could actually serve in overseas units or become fully incorporated into the Army. Weatherford notes that "the majority of women, of course, would work in that clerical area that was uppermost in Congressional minds when they thought of jobs that women did better than men - even in the progressive Army Air Force, about half of all Air WACs were in office jobs. Traditional though the field was, however, this new setting made the work new and interesting.”29 Women also received training to work as linguists, communications operators, cryptographers, and social directors. Courses in Army structure and training specific to the role that the WAAC would serve in the war also had to occur; specific training as weather observers and communications specialists were undertaken by the women. Anna Marie’s training notebook is filled with detailed notes on such topics as reasons for separations from service, military courtesy and discipline, courtesies to the American flag and the national anthem, and the care of clothing and equipment. The

\footnotetext{
${ }^{27}$ Letter Home, Anna Marie Fisher to Stella Fisher and Steve Fisher, December 26, 1942, 6.

${ }^{28}$ Ibid., 6.

${ }^{29}$ Weatherford, American Women and World War II, 63.
} 
women were even familiarized with standards of Army recreation, which, according to the officer who taught Anna Marie's course on the subject, "builds morale, relaxes [the women], makes groups more alert. ${ }^{, 30}$

These initial training camps and boot camps served to incorporate and familiarize the women not only with what they would be doing to help defend America, but also with general military structure, formation, and ideology. Each of the various branches of the military had a somewhat different approach to training the new female recruits, yet, all of them emphasized military structure and task fulfillments, both clerical and non-clerical, which would help in their service. In their collection of stories about the service of women in the war, Gail Braybon and Penny Summerfield wrote about the impact that women had in the war and the tasks which they participated in for the first time in American military history. "In 1939-45...women handled anti-aircraft guns, ran the communications network, mended aeroplanes and even flew them from base to base. By 1943 12,000 servicewomen had been posted abroad. Although they did not in general fire weapons, women did jobs far more like men's than they had twenty-five years earlier [during World War I].”31 These efforts during training and the excellent service of the WAAC clearly made an impact on the high military brass. Emily Yellin writes that by the end of November 1942, "Eisenhower began asking for WAACs to staff his office as stenographers and for French-speaking WAACs to operate switchboards in the North African theater...by the end of 1942 [when Anna Marie was beginning her training at

\footnotetext{
${ }^{30}$ WAAC Training Notebook, Recreation Section, December 1942.

${ }^{31}$ Braybon and Summerfield, Out of the Cage, 5.
} 
Daytona Beach], the first WAAC officers were sent to Africa, and in January 1943 the first company of enlisted women arrived in Algiers., ${ }^{32}$

For the next two years, women would serve in every single theater of the war and would become an integral part of the Allied war effort. Women participated in many varied tasks, performing necessary duties while maintaining their femininity, gaining respect for themselves in the national arena while changing gender conventions. Their work arrangements and support personnel were similar to and in many cases the same as those which the men utilized. The only real difference, other than the fact that women held auxiliary status until September 1, 1943, was that men were able to perform a much wider range of tasks for the military in both combat and non-combat roles. Even still, the women of the WAAC were important both overseas and domestically. "Through the course of the war, WACs were deployed to the three main parts of the Army. Forty percent were assigned to the Army Air Forces in such jobs as weather observers and forecasters, radio operators and repairwomen, control tower operators, and aerial photograph analysts. Another 40 percent of WACs went into the Army Service Forces, working as cryptologists, photographers, telephone operators, mechanics, medical lab technicians, and other more clerical jobs. And 20 percent became part of the Army Ground Forces...in secretarial jobs and motor pools." ${ }^{\text {,33 }}$ All of the women who performed these duties are considered veterans of the war, though none of them served in direct combat.

Domestically, during World War II, no military battles were fought; yet, a military-industrial machine accelerated support for the war and was fueled by the efforts

\footnotetext{
${ }^{32}$ Yellin, Our Mother's War, 121-2.

${ }^{33}$ Ibid., 116.
} 
of both men and women. Overseas, women did not perform combat duties, yet, some were killed in war action. Certain people have spoken out in favor of women's participation not only on the fringes of the war, but also in favor of women in combat, or at least, some form of more direct participation. In The Journal of Military Affairs, historian D’Ann Campbell writes about the issues that women have had to face in serving in the military. "The restrictions against women in combat that persisted for decades in the United States were not based on experimental research (quite the reverse), or from a consideration of the effectiveness of women in combat in other armies. The restrictions were primarily political decisions made in response to the public opinion of the day, and the climate of opinion in Congress. Still horrified by Belleau Wood, Okanawa, and Ia Drang, many Americans to this day visualize 'combat' as vicious hand-to-hand knife fighting, ${ }^{34}$ which of course is only a tiny fraction of what truly makes up overseas combat. Military women and civilian women who were overseas and helping to defend the United States were held to different standards throughout the world than most of the other American troops. Leisa Meyer writes about those standards. "In May 1943, a new War Department policy on the use of female civilians overseas prohibited their employment in 'active combat areas' but noted that 'Members of the WAAC, ANC, and other female military organizations... are excepted...this Army policy underlined the different status of the two groups, female civilians viewed as 'women,' and protected accordingly, and Wacs, employed as 'soldiers' with many of the accompanying risks.”35 Women took many risks, literally and figuratively, in joining the WAAC and defending their nation during World War II.

\footnotetext{
${ }^{34}$ D’Ann Campbell, "Women in Combat: The World War II Experience in the United States, Great Britain, Germany, and the Soviet Union,” The Journal of Military History 57, April 1993, 322.

${ }^{35}$ Meyer, Creating G.I. Jane, 86-7.
} 
Only thirty percent of the women who signed up for WAAC service served in an overseas theater; Anna Marie was one of these women. She spent time in North Africa, Rome, Capri, and other parts of the Italian peninsula. In a letter dated Christmas Day, 1944, Anna Marie writes that she was "up fairly early the next morning and we went to the Vatican City - were personally introduced to the Pope and he gave me a rosary - after the audience we toured the Vatican, the Sistine Chapel and St. Peters. ${ }^{„ 36}$ Obviously, tourism was not the main focus of the women in serving in the WAAC, however, it was an important aspect of camaraderie and Anna Marie writes in numerous letters that seeing those famous buildings, sites, and historical ruins boosted her morale; certainly, doing these types of things helped the women who were serving overseas.

Anna Marie began in Italy serving in the Signal Corps, however, she requested a transfer from that duty in November 1944, hoping to transfer to the public relations department. She writes in a letter dated on November 5, 1944 that "I will be released from duty with the Signal Corps and be put on temporary duty with Public Relations - it is so exciting that I'm six feet up in the air. ${ }^{37}$ In that same letter and in other letters, Anna Marie discussed the duties of the Public Relations Department; these include helping to set up meetings of important military personnel when they were traveling through Anna Marie's station, and organizing Congressional visits when Congressmen came to visit the troops. Revered WAAC figures also came to visit while Anna Marie was in Rome. Anna Marie wrote that "I've been appointed aide-de-camps to Clare Booth Luce when she makes her tour of this theater with the House Military Affairs Comm. - it was a complete surprise to me and I am very happy about it...she is bringing Wac Lt. Col.

\footnotetext{
${ }^{36}$ Letter Home, Anna Marie Fisher to Stella Fisher, December 25, 1944, 3.

${ }^{37}$ Letter Home, Anna Marie Fisher to Stella Fisher, November 5, 1944, 2.
} 
Florence Newsome, who is Gen. Marshall's secy. with her and stacks of Congressmen.”38 These meetings and visits helped to boost morale among the community and among the women serving in the WAC.

The social life of the women in the WAC was another way in which the stress of serving in wartime was eased. Anna Marie discusses the social life aspect of service more than any other aspect in her letters, detailing the many men that she meets, their physical and personal characteristics, and the physical traits of certain men that she met. While the army praised the contributions of WACs like Anna Marie, throughout the war, it fought a wide-ranging slander campaign against female soldiers. Rumors circulated during the war that venereal disease was rampant in the WAAC. In fact, this was not true. Pregnancy was also a rumor that circulated widely, however, few women became pregnant while serving in the WAAC and those that did were married. Those that did become pregnant did so while back home with their husbands, not by sleeping around with men in camp. Yellin writes that "A converted slander campaign against Army women arose in 1943. Rumors had been circulating about the moral character of women who joined the WAAC during the first year of its existence...one rumor said large numbers of WAACs had to be returned from North Africa because they were pregnant, a condition that meant immediate dismissal from military service. ${ }^{39}$ Wildly exaggerated rumors were spread around military circles; one was "that 90 percent of WAACs were prostitutes and 40 percent had gotten pregnant while 'servicing' male troops. Word had also spread that all applicants for the WAAC who were found to be virgins during Army physicals were immediately rejected. And numerous obscene jokes about WAAC's

\footnotetext{
${ }^{38}$ Letter Home, Anna Marie Fisher to Stella Fisher, November 5, 1944, 1.

${ }^{39}$ Yellin, Our Mother's War, 130.
} 
anatomical specifications went around among Army men at home and overseas." ${ }^{40}$ All in all, "the rumors were just that. The WAAC had a venereal disease rate so low as to be virtually nonexistent, much different from the relatively high VD rate among male Army personnel. WAACs were never issued any contraceptives or give information about using contraceptives, unlike the extensive program to issue military men condoms at all military instillations. ${ }^{41}$ Clearly, different standards in regard to sexuality and dating existed for men and women during World War II.

Rumors circulated around the Army and around America that in addition to pregnancy, lesbianism existed within the ranks of the WAAC. A concerted effort was made by the Army to dismantle these rumors and decrease any overt "mannishness" that might be portrayed within the WAAC. Leisa Meyer writes that "in a culture increasingly anxious about women's sexuality in general [due to the shifting gender conventions], and homosexuality in particular, the formation of a sex-segregated woman's unit within an otherwise wholly male institution sparked a storm of public speculation as to the potential breakdown of heterosexual norms and sexual morality." ${ }^{42}$ During the 1940s, lesbianism and homosexuality in general were looked at as diseases and as detractions from society. The Army and most of the women in the WAAC did not want to portray the WAAC as condoning homosexuality in any manner. Suspicion and accusations of lesbianism became commonplace among those who were against the women serving at all. For sure, some lesbianism did exist in the close confines of WAAC training camps and dorms, however, heterosexuality was much more common. John Costello writes that "it may be

\footnotetext{
${ }^{40}$ Yellin, Our Mother's War, 130.

${ }^{41}$ Ibid., 131.

${ }^{42}$ Leisa Meyer, “The Lesbian Threat: Within the World War II Women’s Army Corps,” contained in Women and War in the Twentieth Century: Enlisted With or Without Consent, Nicole Ann Dombrowski, ed. (New York: Garland Publishing, Inc., 1999), 186-7.
} 
presumed that the close confines of their barracks enabled many women both to observe and discover homosexual attractions in themselves. While most did not become lesbians as a result of their wartime encounters, many acquired a tolerance of and understanding for such tendencies in others that contributed to a relaxation of their prejudices." ${ }^{\text {,3 }}$ Some elements of the population even thought that women who wanted to serve in the military were automatically homosexual because of that desire. Meyer writes that "a woman's expressed desire to join the military could in itself be cause for suspicion, because 'real women' would not want to be 'soldiers' at all. Consequently, articulated fears of the kind of woman who might flourish in a martial environment, regardless of suspicion of particular sexual behaviors, were rife with allusions to lesbianism and followed the corps from its inception." ${ }^{44}$

Despite all of these rumors and distractions, the women of the WAAC persevered on and continued in their service. The Army fought these rumors by emphasizing femininity and respectability of the women, which was expressed both in training and in the clothing that the women wore. While dress and clothing issues were important, Ann Allen writes that some branches of the military viewed the issue as a minor one. "The secretiveness concerning clothing in relation to female anatomy only piqued the public's curiosity because the subject was being handled in such a Victorian manner. The Navy solved this dilemma by giving WAVE recruits a supplemental allowance to buy underclothes.”45 In her letters home, Anna Marie often asks her mother to send certain articles of clothing; a pair of pink shorts in one instance, some sundresses in another. The dress of the women, both while in uniform and while off-duty, was important for both the

\footnotetext{
${ }^{43}$ Costello, Virtue Under Fire, 72.

${ }^{44}$ Meyer, "The Lesbian Threat," in Women and War in the Twentieth Century, 187.

${ }^{45}$ Allen, "The News Media and the Women’s Army Auxiliary Corps," 79.
} 
women serving and for the American politicians who supported the war. Respectability was important and the women of the WAAC fought for that trait, as did the Army itself. However, early on in the war, during the recruiting efforts in 1942, the uniform situation was almost comical in the eyes of one author. "Showing totally illogical reasoning, women's uniforms were designed to emphasize femininity, while disregarding how women would function in them. Size 18 bathrobes were only one example of the irony of stressing vive la difference while simultaneously ignoring it. Margaret Flint, who was a WAAC photographer, wrote of the difficulties posed for her by supply. She rode an army bicycle, not designed for a lady.”46 In an effort to uphold and portray respectability, WAACs were also, for the most part, held to a seemingly higher standard than their male counterparts.

WAAC leadership sought to protect the reputation of the corps by carefully controlling the behavior of servicewomen. In many cases, the women of the WAAC were held to a higher standard than the men who were serving in the Army. Discipline was enforced more strictly (this is reinforced in Anna Marie’s letters) among the WAAC units than it was among the male units; this was true overseas and in America. Doris Weatherford writes of this double standard that "whether in quarters or in class, WAACs were under constant military discipline. Military regulation was not exactly the standard, however, when it came to the inclusion of sex education in G.I. Jane’s curriculum.”47 The men who served in World War II were given much more in the way of sex education than were the women who served in the same war, often at the same places, often during the same tours. This is indicative of the way in which men were viewed by the military

\footnotetext{
${ }^{46}$ Weatherford, American Women and World War II, 87.

${ }^{47}$ Weatherford, American Women and World War II, 52.
} 
at the time, basically, that they could have sex with women during duty, whether the men were married or not, and that the Army would either ignore it or even support it (as the earlier allusion to condoms indicated). Women of the WAAC were more closely regulated in regard to home passes, bedchecks at night, and even locale passes while on tour overseas. The WAACs were also subjected to "any number of military stupidities that the civilian did not have to suffer; for instance, during most of the war, WAC field units operated under the ASF requirement of four hours' weekly repetition of basic courses. This meant that after a long day of work, WACs had to sit in boring classes at night, tiredly restudying what they already knew, while the civilian had her leisure hours free." ${ }^{48}$ This close regulation, in the minds of those in charge, would help to build character, pride, and respectability among the WAAC.

As historian Leisa Meyer has argued, Army and WAAC leaders were determined that female soldiers would not threaten "male power" in the military or threaten the conventional gender order of the larger society. There was a distinction drawn between the women and the men from the outset of the female military programs, both in their service and in their images that would be portrayed to the public. "The task of achieving legitimacy for the WAC involved not only created space within the public arena for 'female soldiers' but also creating a place for women within the male military. In accomplishing these goals, female military leaders, especially Colonel Hobby, believed it absolutely necessary to construct the 'female soldier' as distinct from her male counterpart." ${ }^{49}$ Those organizing the WAAC and the officers in charge of the organization wanted to make sure that the women did not disrupt the existing and

\footnotetext{
${ }^{48}$ Ibid., 72.

${ }^{49}$ Meyer, Creating G.I. Jane, 62.
} 
predominant military hierarchy. Meyer reinforces what other WAAC historians have written by writing that 'the entire construction of the WAC by corps' leaders was organized to limit public fears that the state was advocating changes in sexual, gender, race, or class hierarchies. The WAC leadership attempted to assuage public concerns about the potential sexual independence and victimization of servicewomen, for example, by depicting female soldiers as feminine and chaste. ${ }^{, 50}$ These efforts were well-received by most members of the military and helped to lessen the impact of the shifting gender conventions, however, the women of the WAAC would not be solely defined by military policy.

To see exactly what the media of the time thought about the WAAC, it is important to view contemporary magazines and periodicals, which were full of WAAC articles and advertisements. Magazines such as Life, Time, Mademoiselle, and The Saturday Evening Post offer the researcher a valuable insight into WAAC service. Ann Allen writes that "no magazine during the lifespan of the Auxiliary gave as much coverage to the WAAC as did Mademoiselle. In prewar days it had been primarily a fashion magazine for women of the upper-middle class. In September following the graduation of the first WAAC officers candidate class, Mademoiselle published its first portrait of WAAC life...thereafter until the Corps converted to full Army status, Mademoiselle published a monthly autobiography of military women.”51 Other magazines did similar things, publishing articles about specific WAACs or, in some cases, sending their own reporters to experience WAAC life and report on the way in which the women trained and lived. According to Life magazine, WAACs and

\footnotetext{
${ }^{50}$ Ibid., 8.

${ }^{51}$ Allen, "The News Media and the WAAC," 80.
} 
servicewomen in general were no longer experimental by March 1943. "By last week, the Waves and Waacs were no longer military experiments. They were military realities, having appeared for duty with startling effects at Army and Navy posts all over the country." 52 According to a similar magazine, Time, the burden of proof to show that women were capable of military service was wholly placed upon the women who initially signed up and were enlisted at Fort Des Moines, Iowa, in mid-1942. "They had to prove that: 1) they were emotionally suited to Army life; 2) they were adaptable enough to take to the Army's ways and like them; 3) they were intelligent enough to master what they had to learn in a brief six weeks." ${ }^{53}$ For the most part, the women of the WAAC quickly proved themselves, as the earlier quote from Life shows. The WAACs had to prove themselves in this manner both at home and abroad. A September 1944 article in The Saturday Evening Post stated that "ever since the first WACs appeared here rather timidly, a little more than a year ago, the British Isles have been a proving ground for G.I. Janes.

Karen Anderson writes that World War II was important for a number of reasons, most importantly because it marked a temporary retreat from common conceptions about women that would serve as an example for reformers a generation later. She writes that “World War II marked a temporary retreat from prevailing notions of women’s capabilities and proper roles. The manpower demands of the industrial and war machine created a situation in which the employment of large numbers of women became mandatory." 55 This addition of women into the workforce and into the military was

\footnotetext{
52 "WAACS and WAVES,” Life, 15 March 1943, 72.

53 "They Work Too Hard," Time, 24 August 1942, 59.

${ }^{54}$ Ernest O. Hauser, “Those Wonderful G.I. Jane’s,” Saturday Evening Post, 9 September 1944, 27.

${ }^{55}$ Anderson, Wartime Women, 4.
} 
another contributing factor to the shifting gender conventions. Anderson is referring here to women working in domestic industries to support the war while also alluding to women such as Anna Marie who served in the military. These actions and labor on the part of the women had a positive effect on both the war effort and the women themselves. Susan Hartmann writes that "Despite their unequal treatment, military service was a positive experience for most of the 350,000 women who volunteered...war service itself expanded the horizons of these women as it took them far from home and placed them in novel situations. ${ }^{56}$ Women benefited greatly from service in the WAAC. Hartmann writes that "Sixty-five thousand of them took advantage of veteran's benefits for college or graduate study...pride in newly discovered capabilities was nearly universal. ${ }^{, 57}$

The servicewomen served for nearly as long of a duration as the men, creating a sense, in some instances, of domestic instability among the families of the women, even though women with dependents were not allowed to serve. "Although the war offered women new opportunities for independence and role flexibility and challenged conventional stereotypes regarding women's physical and emotional makeup, it also promoted considerable apprehension about family stability and a strong desire to return to more traditional family forms once the war was over., ${ }^{58}$ While women and men did return to traditional family forms following the war, the service of the women in the WAAC and the WAVES upset traditional gender roles and behaviors while shifting gender conventions. Servicewomen and young women who moved to cities to contribute to the war industries helped to push for new ground for American women. These women

\footnotetext{
${ }^{56}$ Susan M. Hartmann, The Home Front and Beyond: American Women in the 1940s (Boston: Twayne Publishers, 1982), 47.

${ }^{57}$ Ibid., 47.

${ }^{58}$ Anderson, Wartime Women, 111.
} 
gained a new independence in addition to feeling a sense of accomplishment and pride in their service to the country. Also, as these young women accomplished these things without parental supervision and in most cases on their own, they created a greater respect both for themselves and for women in general. For the first time, women gained regular stature in the Army and were vital in the American effort to win World War II.

There were a number of reasons that the WAAC was crucial in helping the Allies win World War II. “The WACs were like tonic,' said a European commander. 'They gave men competition on the job and a new interest in social life on the base. The Wac Detachment was the finest morale booster that the base ever had.' Particularly in these overseas locations, WACs did indeed give a new dimension to social life."59 WAAC servicewomen contributed more than just socially; they also helped to decode and break Axis communication relays in addition to helping with military transport and coordination. Anna Marie reflected these sentiments in many of her letters. She discussed dates, dinners, formals, group meetings, and other instances of normal interaction among young people. WAACs helped to maintain a sense of normalcy in the military that reflected both domestically while in training and boot camps and overseas while serving in theater. The WAAC also "offers women an opportunity to help win the war by performing non-combatant duties so men can fight." ${ }^{60}$ The performance of these non-combatant duties helped to shift the role of women in America and also changed the way in which America viewed its young women. Anna Marie felt that these opportunities were invaluable to the war effort. She wrote that "American women are discovering that this is not solely a war away from home: it is a war at home and they are

\footnotetext{
${ }^{59}$ Weatherford, History of Women in America, 89.

${ }^{60}$ WAAC Recruitment Postcard, 1942.
} 
in it just as women in England found themselves in the war soon after it began.”61 Anna Marie's words here reflect the government's advertising and propaganda efforts of the early war years in a concerted effort to boost morale and recruitment. In the following pages, a closer look at her service will show that the women of the WAAC played an intriguing role in World War II and helped to shift American gender conventions.

${ }^{61}$ Anna Marie Fisher, Women are in it Too, early 1943. 


\section{Chapter Three: First Lieutenant Anna Marie Fisher}

The letters of First Lieutenant Anna Marie Fisher of the Women’s Army

Auxiliary Corps offer a valuable insight into the experience of women who served in the WAAC and in other military organizations during World War II. Her letters date from December 15, 1942 all the way through March 28, 1945. In addition, her military training manuals, notebooks, and class notes from boot camp offer insights into training and education during boot camp. Anna Marie's letters, almost of all of which are sent to her mother, Stella Fisher, in Charleston, West Virginia, are often coupled with pictures and postcards depicting the many places that she was able to travel as a soldier. Without the military, there is little chance that Anna Marie or most of the other women in the WAAC would have been able to see the areas of the world that service in the military allowed them to see; these areas included Tunisia and the ruins of the great ancient city of Carthage, as well as Capri, Rome, and the Italian peninsula. Susan Hartmann writes that "It was military expediency that afforded women this opportunity. In the twentieth century, transformations in warfare had produced a military establishment capable of utilizing women, and the feminization of areas in the civilian economy had created an occupational structure which provided women with skills required by the military.”1 These skills and this utilization of women marked a breaking of new ground for American women. Due to the actions of women in World War II, new opportunities were opened up for women in the United States and American gender conventions shifted to include women in more areas.

\footnotetext{
${ }^{1}$ Hartmann, The Home Front and Beyond, 47.
} 
Anna Marie felt that she had been called to volunteer to serve in the Women's Army Auxiliary Corps. She was a young woman upon her arrival in Daytona Beach, only twenty-one years old. Growing up in Charleston, West Virginia, Anna Marie had held desires to leave West Virginia and see the rest of the United States since early in her youth. She collected articles about overseas locations that appeared in the Charleston Daily Mail, especially articles that dealt with Hitler’s movements around Europe during the late 1930s and the developments in Italy and Spain that coincided with the onset of World War II. She was interested in current affairs and world history, telling her brother on numerous occasions that she wanted to major in either History or Journalism when she went to college. The WAAC offered Anna Marie the chance to fulfill all of these hopes that she held and though she was quite young upon her enrollment in the program, her performance reports indicate that she did quite a good job both in training and while on duty. Daytona Beach was the first place that she went to develop the skills necessary for the WAAC; it is clear in her letters that she thoroughly enjoyed being in a warm, sunny location during the middle of what would have been a freezing winter in the mountains of West Virginia.

In her early letters from the Florida coast, which was in sharp meteorological contrast to her home of Charleston, West Virginia, Anna Marie writes about the "luxury" that accompanied her early WAAC training. Due to insufficient housing at the actual WAAC training base in Daytona Beach (and at numerous other training bases for both men and women around the United States), Anna Marie and her fellow enlistees lived in much nicer accommodations than the standard Army barracks. "We have moved to the Hotel Riviera. It was the most exclusive hotel here. We have a private swimming pool, 
also the ocean, eat dinner at the Trocadero which once was a nightclub...there is a lovely garden...don’t worry about me because I am having a picnic.”2 In her first letter from Daytona Beach, written on stationary that at the top shows scenes of women in bathing suits standing on the beach, Anna Marie discusses the Hotel Clarendon, which is where she and other WAACs lived before moving on to the Hotel Riviera. "We are in Hotel Clarendon on the beach facing the ocean. At night you can see the white caps and hear the waves hit the shore. It's like living in another world.”3 The experience of living in nice hotels on the beach in Florida while serving in the military does seem to be somewhat of an oxymoron. Anna Marie's optimism and upbeat nature in these early letters, something that continues throughout almost all of her letters, is marked. In regards to her first impression of the other soldiers and of Daytona Beach in general, she writes that "This place is jammed with soldiers, ensigns, and fliers. Maybe one is a millionaire. Will write as soon as I get the time.” ${ }^{4}$ The experience of taking in a whole new experience was thrilling to Anna Marie, as it was too many others of the men and women who volunteered for service.

Upon transferring to the Hotel Riviera, six miles away from her initial location at Daytona Beach, Anna Marie, who once again was in superb accommodations, wrote about what was ahead for her and for the other WAACs as well. She wrote that "We had our interviews and even put in communications. Our basic training is four weeks and officer's school is two months...I have a room with two girls from Texas...it’s just like living in a college dorm.” ${ }^{5}$ Anna Marie also wrote about how the military environment

\footnotetext{
${ }^{2}$ Letter Home, Anna Marie Fisher to Stella Fisher, December 18, 1942, 3.

${ }^{3}$ Letter Home, Anna Marie Fisher to Stella Fisher, December 15, 1942, 1-2.

${ }^{4}$ Ibid., 4.

${ }^{5}$ Letter Home, Anna Marie Fisher to Stella Fisher, December 18, 1942, 2.
} 
that took over the nation following the attacks on Pearl Harbor was especially marked in Daytona Beach. With a WAAC base and an air base for men, as well as other military installations and organizations, Daytona Beach was crowded with soldiers. In her second letter home, Anna Marie wrote about living in this environment. "Civilians look out of place down here. Men in uniform and Waacs are so common that no one pays any attention to them." ${ }^{\prime 6}$ This abundance of military personnel led to an expected amount of interaction among the men and the women, which was thrilling and exciting both for the young women and for the young men. Anna Marie seemed to be very excited about meeting all of these new people. However, Anna Marie’s tone of optimism fades a bit in her third letter from Daytona Beach, partly because she begins to feel homesick for the first time, a natural feeling for a young woman.

The Christmas holiday in 1942 was a sad one for Anna Marie, as she was away from home over the holidays for the first time in her life. This feeling is reflected in her letter written two days before Christmas and mailed to her mother on Christmas Eve. Anna Marie began her letter by writing that "At this point I'm feeling sort of forlorn...I've been a little homesick a few times especially at first when it was all so confusing. Now I'm pretty well settled into the swing of things."” In this letter she also discussed the stress of her current classes and how much studying that she was doing, so much that the women hardly ever had the time to go out. ${ }^{8}$ This lack of social activity was unusual for someone with a social life as vibrant as Anna Marie. The lack of parties was not the only thing that was affecting the women; the heat of the area was difficult for some of the women to take as well. Anna Marie wrote that "This morning at reveille two

\footnotetext{
${ }^{6}$ Letter Home, Anna Marie Fisher to Stella Fisher, December 18, 1942, 3.

${ }^{7}$ Letter Home, Anna Marie Fisher to Stella Fisher, December 23, 1942, 1.

${ }^{8}$ Ibid., 1.
} 
girls fainted in ranks and lots fell out sick. So far my luck has held and I'm not sick.”9 Having mentioned earlier in the letter that she was homesick, Anna Marie again alluded to those feelings but again indicated that she had a few activities over the next couple of days to fill her time and occupy her mind. These activities included dinner on Christmas Eve with a family whom she had befriended as well as some WAAC programs that were also scheduled for Christmas Eve. As in the earlier letter, Anna Marie also described the overcrowded condition in Daytona Beach. "Stamps are as scarce as hare’s teeth here. You can imagine with two thousand WAACs, two thousand soldiers and sailors and the civilian population which is a little over 2,000. We're practically running them out of their own town!"10 The overcrowded nature of Daytona Beach, with more than two times the number of enlisted men and women than actual residents, helped to keep the women busy.

After Christmas, Anna Marie wrote again to her family, showing more optimism and revealing that the Christmas holiday really was not as bad as she had thought that it might be. The feeling of forlornness and homesickness was absent from her second to last letter from Daytona Beach, which may be partly due to the fact that the food situation for the women apparently had improved. Anna Marie wrote that "So far the food has been awful but all the girls voted to take it over so we did and now it is much better."11 In later letters, she mentions that she missed the cooking at Daytona Beach because of the fact that the girls took the kitchen over and were able to cook whatever they wanted at the time. This gave the accommodations more of a homely feel according to Anna Marie; in addition, she wrote that the fainting that happened before Christmas continued among the

\footnotetext{
${ }^{9}$ Letter Home, Anna Marie Fisher to Stella Fisher, December 23, 1942, 2.

${ }^{10}$ Ibid., 2.

${ }^{11}$ Letter Home, Anna Marie Fisher to Stella Fisher, December 27, 1942, 2.
} 
women following the holidays. "Yesterday four girls fainted in ranks and three the day before. I know something's wrong because I haven't been sick yet and you know I'm usually the first one."12 The women who were fainting because of the heat were having a difficult time adjusting to structure and organization that previously had not been in their lives. Anna Marie also wrote about the inspections and the competitions that surrounded the cleaning of the rooms in the hotel. "Our rooms are inspected each day and they even look in the waste baskets to see if they can find any dust. We're the best company on our post and got the prize for the best inspection...I'm sending you a picture.”13 The tone in Anna Marie's letters seems to indicate that these sorts of cleaning competitions and other group activities really helped women to adjust to their new lives in the military. In addition, it also helped the military adjust to life with women.

In her last letter from Daytona Beach, which was also her lengthiest letter while stationed in Florida, Anna Marie wrote about the ways in which the military was helping the women overcome self-consciousness and build self-confidence. She wrote about the various positions on her post that she held in an effort to train and in an effort to build self-confidence and skill. "So far [I] have been fire guard, K.P. slave, squad leader and tomorrow comes my big moment as acting platoon sergeant. They make us do these things to overcome self-consciousness and, as the whole company goes into fits of laughter each time a wrong command is given, it really serves our purpose.”14 A bit sarcastic in this statement, which is unusual for letters, Anna Marie also described the troubles that women were having while in training. These difficulties included problems with marching in formation and difficulty making all schedules on time and establishing

\footnotetext{
${ }^{12}$ Letter Home, Anna Marie Fisher to Stella Fisher, December 27, 1942, 4-5.

${ }^{13}$ Ibid., 5-6.

${ }^{14}$ Letter Home, Anna Marie Fisher to Stella Fisher, January 5, 1943, 2-3.
} 
punctuality. At times, a humorous story accompanies Anna Marie’s descriptions of life in training camp and these stories helped women deal with being away from home and with feelings of homesickness. She wrote in early January, again with hints of sarcasm, that "our marching is quite out of this world - never everyone in step at once and today three girls went the wrong way and marched into a palm tree."15

The women training and serving in the WAAC used incidents such as the palm tree incident to lighten the mood of camp and to help the women themselves deal with military service. Another way in which these women took their minds off of the actual work and military service was by engaging in many social activities. To Anna Marie, these social activities were crucial and were usually the centerpiece of both her letters and her mind. Following her service in Daytona Beach, Anna Marie completed basic training at Fort Des Moines, then was sent to Fort Devens, Massachusetts, followed by a stay at Fort Oglethorpe, Georgia. After all of this training and stationing in the United States, Anna Marie was stationed in North Africa and finally in Italy. Throughout all of this time, Anna Marie’s social life and social activities flourished. She devotes much of her letters to discussing dances, balls, dates with men, and other social activities which she took place in to ease her mind off of the stresses of service during wartime. It is almost astonishing in some of her letters simply the amount of time and space that she devotes to writing about social goings-on and the many non-military aspects of military life. These social activities give a real insight into the life of a female soldier, as dances and suntanning are not the first two things that jump to mind when thinking about the military. Many of these social activities, such as dances, balls, and dinners, were set up by the military while some activities, such as singular dates and tours into famous areas of

\footnotetext{
${ }^{15}$ Letter Home, Anna Marie Fisher to Stella Fisher, January 5, 1943, 3.
} 
Europe, were simply spontaneous decisions made by either Anna Marie or her date. All of these activities helped to ease the stress of military service.

In addition to telling stories and talking about her dating and social experiences, Anna Marie also made light of the required classes that the WAACs were forced to take as part of Army training. She wrote that "Class is a very unique part of Army routine. It consists of rushing into the classroom, killing a few on the way, to get a good seat. A good seat is one in the last three rows. There they gather in groups of threes; two sentinels and one sleeper. Letter writing is common although frowned on by the teachers. Tests are unknown which is a good thing." ${ }^{16}$ This slight humor that Anna Marie wrote home about to her mother is one of the many quirks of Army life that accompanied serving in the military. Also, it shows that these young women, some of whom are no more than two years removed from the completion of high school, simply were acting like regular students. These stories are also quite telling of the difficulties that women tended to encounter, not always but more than sporadically, in adjusting to serving their nation during wartime. Anna Marie continues in the same letter, discussing the bond that the trainees were forming as a result of their service together and their shared experiences in the camps, hotels, and training bases of Daytona Beach. She wrote that "Each day we get a little more used to each other and now that we are at last acclimated, will have to move again."17 The move for the women came very soon after the writing of the previous letter and it was a move to the central WAAC training camp of Fort Des Moines, Iowa.

\footnotetext{
${ }^{16}$ Letter Home, Anna Marie Fisher to Stella Fisher, January 5, 1943, 4-5.

${ }^{17}$ Ibid., 8.
} 
Following her stay in Daytona Beach, Anna Marie and her accompanying WAAC unit switched stations, going first to basic training and subsequently to Ayer, Massachusetts, where Fort Devens was located. Before reaching Fort Devens, however, Anna Marie completed basic training, from which she wrote no letters. She graduated from the Women’s Army Auxiliary Corps Training Center in Fort Des Moines, Iowa on April 22, 1943. Anna Marie was one of only two women from the state of West Virginia in her graduating class (the other being Olive Eloise Edgell, from Moundsville, West Virginia). Upon graduation, Anna Marie was a third officer and a member of the Twenty-Fourth Officer Candidacy Class; at this point, Anna Marie was also made a First Lieutenant, the ranking which she would hold throughout her service in the WAAC. Another benefit upon graduation from WAAC training was that Anna Marie was able to travel home to Charleston and be with her mother and brother for a short period of time, the first time that she had been home in almost five months. Charleston, like many other cities in America, was fully engaged in the war effort and Anna Marie’s younger brother Steve was also joining the military. In addition, many of her friends were working in war industries, the coal industry, and in support industries; the entire homefront seemed to be fully engaged in the war effort.

While both men and women were engaged in the war effort and women entered new jobs en masse for the first time, the standards remained higher for women while the pay remained higher for men. In addition, not all people were excited about women entering the workforce in mass quantities. Elaine Tyler May writes that a "Fortune magazine lamented: 'There are practically no unmarried women left to draw upon...Many thoughtful citizens are seriously disturbed over the wisdom of bringing 
married women into the factories."18 Though some were disturbed about bringing women full-throttle into the workforce (and Anna Marie was not one of them), the women entered into industries, though not as expansively as is widely perceived. May writes that "In spite of their visibility, women still remained in a fairly small number of occupations. For all the publicity surrounding 'Rosie the Riveter,' few women took jobs that were previously held exclusively by men, and most of those jobs ended at the conclusion of the war...although more and more women were welcomed into the paid labor force, most of them still ended up in low-paying, sex-segregated jobs.” ${ }^{\text {19 }}$ Anna Marie was lucky to be in one of the few occupations that previously had not been held by men; in addition, while Anna Marie tragically did not live to the end of the war, other women with whom she served continued in military service. Some women did capitalize on the opportunity to enter new arenas and Anna Marie was one. Completing the WAAC training course at Fort Des Moines was one of the first major steps in accomplishing her goals.

After basic training, Anna Marie went to Fort Devens, Massachusetts, in late April 1943. While in Massachusetts, her letters were marked with an air of expectation. She wrote that there was "nothing to do but sit here and wait for something to break. Most of the officers are being sent out rapidly so I expect my traveling orders any day...already I miss being home.”20 It is not difficult to imagine her discomfort and anticipation, as the war seemed to be swirling around while her company remained stationed in America. As her stay at Fort Devens continued throughout the summer, the

\footnotetext{
${ }^{18}$ Elaine Tyler May, "Rosie the Riveter Gets Married,” contained in The War in American Culture: Society and Consciousness During World War II, Lewis A. Erenberg and Susan A. Hirsch, eds., (Chicago: The University of Chicago Press, 1996), 131.

${ }^{19}$ Ibid., 130-1.

${ }^{20}$ Letter Home, Anna Marie Fisher to Stella Fisher, June 3, 1943, 3.
} 
aura of expectancy continued in Anna Marie’s letters. One gets the sense while reading these letters that she was either was ready to either be deployed right away or simply be given furlough so that she could go back to Charleston, a place which she clearly missed, noting so in almost every one of her letters. This sentiment is expressed in many of her letters from Fort Devens; for example, she emphasized her frustration with the situation. "Well, the Army is noted for being so changeable and since I am well aware of that fact, I have no reason to complain. You may have already guessed from the general trend of this dismal letter that plans have once again changed. I am not leaving for Florida as originally planned...don’t get tired of my changing plans because it will probably happen a thousand more times before this is all over."21

These letters tell not only of the constantly changing plans of the Army, but also of how life for the WAAC transpired every day. Anna Marie seems just like a regular civilian woman in some instances, discussing dates, men, social arrangements, and comic shows. She wrote in her letters that these social activities are very important in keeping the morale high for many of the WAAC women. She writes about the "cute guys" that she runs across, going on dates with captains and dancing in officer's social clubs, something that would again happen when she went to serve in Italy. On numerous occasions in her letters (the letters from Ayer and the letters from Daytona Beach), she mentioned sun-tanning and other forms of relaxation that normally would have been done by all females her age. Of course, Anna Marie and her comrades serving in the WAAC attempted to fill their time with as much "normalcy" as possible so that the time would go by quicker and the service would transpire easier. Another reason for the concentration on social life was that these lengths of stationing often were months; for example she was

\footnotetext{
${ }^{21}$ Letter Home, Anna Marie Fisher to Stella Fisher, August 6, 1943, 1.
} 
at both Fort Devens and in Daytona Beach for about five months each. If her letters to her mother are indicative of her true feelings, Anna Marie was much more excited while stationed in Daytona Beach than she was while stationed in Massachusetts.

Anna Marie’s first letter from Massachusetts is dated April 28, 1943. It is clear at the outset that Anna Marie's impression of the Boston area and of Massachusetts was positive. She wrote in the first letter that "I am just mad about Boston and you would be too if only you could see it. All of the streets are very narrow, some cobblestoned, and very crooked - uphill and downhill, never smooth." ${ }^{22}$ She then continued on to describe the various sites that she visited in Boston. These included the birthplace of Benjamin Franklin, Cambridge, the Old North Church, and Beacon Hill itself. Anna Marie also wrote about plans to see the Boston Symphony and how hospitable the Army officers were to the women, which was a big plus in her eyes. She wrote that "we have met quite a bunch of Army officers. They are very nice to us and almost fall on their faces doing things for us. ${ }^{, 23}$ It does not seem, however, that Anna Marie and her group were very active, as she mentioned that frustration existed about the inability to travel home while the women were sitting in Massachusetts unassigned. "We are still unassigned and have done nothing so far but loaf around. It makes me furious when I think that all this time I could have been home. That's how crazy the army is. Most of the quota of officers are here and there isn't a thing for them to do because the new recruits aren’t in yet., ${ }^{24}$ Excitement showed at the end of Anna Marie's letter, however, when she wrote that "Every morning I wake up and have to look twice at my uniform with the bars on it. I

\footnotetext{
${ }^{22}$ Letter Home, Anna Marie Fisher to Stella Fisher, April 28, 1943, 1.

${ }^{23}$ Ibid., 1.

${ }^{24}$ Ibid., 2-3.
} 
still can’t believe it!”25 In early May, due to the fact that her unit remained unassigned, Anna Marie was able to fulfill her wishes and travel home for a few weeks, for the second time in a month, and was forced to return to Massachusetts in early June once again.

In a short letter dated June 3, 1943, Anna Marie again focused on anxiety and the constant hassle of waiting for orders. She wrote that there is "Nothing to do but sit here and wait for something to break. Most of the officers are being sent out rapidly so I expect my traveling orders any day...Some may go overseas.”26 Anna Marie did not receive orders to travel overseas, rather, she was assigned to stay in Massachusetts and help out the new recruits with training and incorporation into the WAAC. In a letter dated June 10, 1943, she wrote that "tomorrow, one hundred and fifty rookies will descend on me. I have no officers and Battalion Headquarters is desperately trying to rake some up for me. I can't very well teach all of the subjects, attend a million meetings a day and run the office too. My first sergeant is still away so I will struggle along with my morons." ${ }^{27}$ Anna Marie also had the chance while at Fort Devens to be a member of an officer board whose responsibility it was to oversee the new officer candidates. This was a good thing for Anna Marie; she wrote that "We selected the girls to be sent to Officer Candidate School and it was a job. Each girl is interviewed for a few minutes and we ask her all sorts of questions. I went thru the same thing just about eight weeks ago when I was selected for O.C. and so I know just how the poor things feel.”28 Anna Marie empathized with the women who were being sent to OCS, as she had recently completed

\footnotetext{
${ }^{25}$ Letter Home, Anna Marie Fisher to Stella Fisher, April 28, 1943, 4.

${ }^{26}$ Letter Home, Anna Marie Fisher to Stella Fisher, June 3, 1943, 2.

${ }^{27}$ Letter Home, Anna Marie Fisher to Stella Fisher, June 10, 1943, 1-2.

${ }^{28}$ Ibid., 2.
} 
the program herself. She was aware that age was not the most important factor in successfully completing OCS, rather, the heart and intellect of the women were what was most important. She wrote that "Some of them [the girls being interviewed] were just 21 and the first thing the other officers on the board would say was that 'she was awfully young.' Remembering the trouble I had I did my best to convince them that age made no difference and in some cases I won my point. Somehow that stupid age thing pops up all the time and those girls were just like I was. I'm glad I got to sit on the board."29

In her next letter, Anna Marie wrote about the things that she had been doing with the new recruits and with the trainees that she had been assigned. Anna Marie was also involved in quite a bit of Army paperwork and clerical duties, jobs that were not nearly as trying as training new recruits. As she was in charge of 118 new recruits during this time, Anna Marie struggled to deal with the totality of such a responsibility. She wrote that "Just try convoying 118 confused rookies all over a post alone with innumerable complications setting in!”30 As for some of the duties that she had to perform and the stresses that the completion of those duties caused, Anna Marie wrote that "Files had to be kept up; thousands of military letters written and all kinds of paper work to attend to. Anyway, I now know how to activate a company from every standpoint. Doing the jobs of four officers at one time enables you to have a finger in every pie and know just what is going on...Had to train my first sergeant and she is a moron."31 Letters such as these reflected the problems that were encountered as the Army struggled with limited resources available while attempting to rapidly expand.

\footnotetext{
${ }^{29}$ Letter Home, Anna Marie Fisher to Stella Fisher, June 10, 1943, 2.

${ }^{30}$ Letter Home, Anna Marie Fisher to Stella Fisher, June 16, 1943, 3.

${ }^{31}$ Ibid., 1.
} 
Anna Marie herself had not been trained to fully incorporate 118 women into the WAAC; she was told to do this and to get all of the women "set up;" she wrote of the difficulties in accomplishing these tasks and the satisfaction of completing them. As far as rank and promotion were concerned, Anna Marie was moving up in the WAAC. She wrote that "I am now Executive Officer and have charge of the first platoon. Am teaching Defense Against Air Attack; Safeguarding Military Information; Interior Guard; Recruiting and Company Administration. Of course I have to teach my platoon drill and physical training. Some life! I hardly have time to breathe. Next month I am praying for a transfer somewhere...I'm just tired of this place.”32 The frustration grew for Anna Marie, as she wrote again a few days later and was complaining of more or less the exact same things. She was short and sweet in some of her complaints and criticism; at one point in her letters she wrote that she was "so tired of this ungodly post."33

Boston seems to have been a popular spot for the women to go whenever they had the ability to leave base. One of Anna Marie's close friends from Daytona Beach and another one of her friends from Charleston were in Boston and she traveled there at every opportunity for a chance to see them and to spend some time away from the "ungodly post.” Anna Marie was able to arrange a meeting with her commanding officer in charge of transfers, and looked forward to this meeting in a letter written after the Independence Day holiday. She wrote that "This afternoon I have an appointment with Captain Trundle, the classification officer. This is the thread that my future hangs by. He is the one who transfers and assigns people to jobs. I will let you know what happens.”34 A few days following that meeting, Anna Marie’s hopes were raised by the possible

\footnotetext{
${ }^{32}$ Letter Home, Anna Marie Fisher to Stella Fisher, June 16, 1943, 5.

${ }^{33}$ Letter Home, Anna Marie Fisher to Stella Fisher, June 28, 1943, 2.

${ }^{34}$ Letter Home, Anna Marie Fisher to Stella Fisher, July 7, 1943, 2.
} 
opportunity of a transfer to Martinsburg, West Virginia. This would have put Anna Marie much closer to home and would have also allowed for more direct communication between her, her brother, and her mother, who was especially worried now that both of her children were serving in the military; Steve was a member of the armed forces as of July 8, 1943.

In addition to possibly having the ability to transfer closer to home, Anna Marie mentioned that her superiors were considering sending her and some of her fellow WAACs to Army O.C.S. for an Army commission, something that Anna Marie was not very excited about. The reason that this was now possible was that as of July 1, 1943, the Women’s Army Auxiliary Corps became the Women’s Army Corps and the women who chose to continue their enlistment would now become full members of the military. In the July 12, 1943 edition of Newsweek, a news short explained the new changes that would come to the WAC in addition to dropping the auxiliary label. "The new statute also removed all personnel limitations (previously 150,000) on the corps and raised the age limit from 45 to 50 . Officers were given regular military titles instead of such designations as first and second officer (thus Mrs. Oveta Culp Hobby, formerly named director, is now a colonel). ${ }^{\text {} 35}$ The full incorporation of women into the Army was another huge step for women in the military and for American women in general. Anna Marie wrote that "The Army may not transfer us in rank or else they may send us to an Army O.C.S. to get an Army commission. As yet we don’t know if ours will be legal. I will resign rather than go thru three months of Army O.C.S. and then not know if I would get a commission or not. We also have to take another physical examination and be

35 “Waac to Wac,” Newsweek, 12 July 1943, 22. 
sworn in. Anyone who wants out can get out now." ${ }^{36}$ Clearly, both the women and the men were a bit worried about what exactly this new change would do; however, Anna Marie and most other WAACs decided to reenlist as WACs.

The new classification did not result in a transfer for Anna Marie. Instead, she was forced to remain in Massachusetts for the better part of a month. Her last couple of letters from Fort Devens were much like the rest of her letters: tinged with an air of expectancy, peppered with hints of frustration and exhaustion, but, most of all, written in a manner that showed how she was attempting to remain upbeat no matter what circumstances came her way. On July 30, 1943, Anna Marie wrote home to tell her mother that her unit in Fort Devens was being deactivated and she was uncertain what exactly that would mean for her future. This deactivation was a direct result of the incorporation of the WAAC into the Army. Anna Marie wrote that "The last, few women in my company are leaving today and the company is being de-activated. I will be very idle from now till I get orders to leave...All we have to do now is box up our files and lock our orderly room door for the last time. I really hate to leave.”37 Again, Anna Marie showed sarcasm in this letter, as it was clear that her early infatuation with Boston and with Massachusetts in general was gone by that time; she was ready to leave, to go anywhere, to receive transfer orders. She hoped that those transfer orders would take her either home to West Virginia or overseas.

In a letter written on August 6, Anna Marie mentioned something to her mother that was unusual, especially unusual for a young 22-year old daughter to write to her mother. Clearly, the social life for Anna Marie at Fort Devens was not nearly as bad as

\footnotetext{
${ }^{36}$ Letter Home, Anna Marie Fisher to Stella Fisher, July 10, 1943, 1-2.

${ }^{37}$ Letter Home, Anna Marie Fisher to Stella Fisher, July 30, 1943, 1.
} 
the work load and the actions of her superior officers. In describing a man that she had mentioned in previous letters, one who apparently was handsome, Anna Marie responded to a question that her mother had asked. "You asked in your last letter if I was planning on keeping him or letting him go. In the face of that I may as well confess that I overlooked one important thing in describing him to you - he is married. Don't be too shocked. When I first joined this organization I thought it a crime to date a married man but they aren’t all wolves so now my ideas are changed."38 Dating married men during the 1940s was not an accepted social practice in most circles, however, circumstances and typical ways of behavior shifted during times of war. This behavior, which clearly was outside the normal networks of control, was due to the fact that there was a greater opportunity to date while stationed at the various bases. Also, this behavior is indicative of the skewed sexual relations that existed in the WAC and among servicemen and servicewomen in general. ${ }^{39}$ The women of the WAC were operating outside normal gender conventions and these actions contributed to the eventual shift that would occur in relation to gender conventions following the war. Anna Marie and her fellow soldiers seemed to have no problem dating married men; in fact, Anna Marie dated multiple married men while serving in the WAC both domestically and overseas. Shortly following the writing of the letter in which she mentioned dating married men, Anna Marie and her unit were transferred to Fort Oglethorpe, Georgia.

Anna Marie began her first letter from Fort Oglethorpe by describing how it felt for her to be in the Deep South, a place with which she was unfamiliar and did not enjoy at all initially. She wrote "Here I am, deep in the heart of something or other - I think

\footnotetext{
${ }^{38}$ Letter Home, Anna Marie Fisher to Stella Fisher, August 6, 1943, 1.

${ }^{39}$ Meyer, Creating G.I. Jane, 127-8.
} 
they call it the South but to me it more closely resembles the Congo...Fort Oglethorpe is about eleven miles from Chattanooga." ${ }^{40}$ As she did in all of the other places where she was stationed, Anna Marie frequented the Officer's Club and the relaxation areas, mainly because those areas were the places where the most men were and also the places where it was most likely to have a good time, according to Anna Marie's letters. There were dances on the weekends, swimming and tennis all of the time, and other recreational activities for the women to do. In addition, Anna Marie's training at Fort Oglethorpe included jobs that she would perform as part of the Communications Company while overseas in Italy later in the war. She wrote that "I am assigned to the $190^{\text {th }}$ Communications Company and like it very much. There is a possibility that it may go overseas but don’t worry about it." ${ }^{41}$ Of course, Stella Fisher would worry about the prospect of her daughter being sent for overseas service. Anna Marie simply was attempting to lighten the weight of the situation and ease her mother's growing anxiety that surrounded the military service of both of her children. Whether or not Anna Marie's words eased her mother's mind, the expectancy for overseas service among the women of the WAC was growing every day.

As far as the situation at Fort Oglethorpe, Anna Marie did not seem to be thrilled about the clothes that the WACs were assigned to wear while in Georgia. She wrote that "We have been issued green overalls and brown field shoes which makes quite a sight. Also, we wear our fatigue dresses. It's horribly hot down here, damp and humid. I just live in a haze of heat and look like a peeled onion., ${ }^{42}$ In her next letter, she again complained of the heat and humidity while writing (surprisingly) that she wished that she

\footnotetext{
${ }^{40}$ Letter Home, Anna Marie Fisher to Stella Fisher, September 3, 1943, 1.

${ }^{41}$ Ibid., 2.

${ }^{42}$ Ibid., 3.
} 
could be back in Massachusetts. She discussed the ways in which she was filling her time in addition to recreation and dating. She wrote, “Am having dinner with Helen and Floe tonite [sic]. They are very unhappy and hate it here. Frankly, I don't like this place either. It is too spread out and as strict as a jail. Besides, it's hot and muggy. I'd give one year’s salary to be back at Devens. ${ }^{״ 3}$ One week following the writing of that letter, Anna Marie was excited to find out that she would be receiving leave in early October, which would enable her to come home for her mother's birthday celebration. In regards to training and duty, Anna Marie wrote that "My training is for six weeks and after that, I don't know. We are fearfully busy and I am worn out at the end of the day. It is lots cooler now and much pleasanter." ${ }^{44}$ The easing of the weather also helped to ease Anna Marie's mind, as the tone of this letter is much less intense than the previous couple of letters.

While at Fort Oglethorpe, Anna Marie and her Communications Company learned the maintenance and operation of switchboards and the science behind various forms of cable communication, a technology that was new and burgeoning during the 1940s. The communications training in Georgia would prove to be quite valuable to Anna Marie in respect to her work and service in Europe, as she was in charge of breaking the communication lines and intercepting German communications in North Africa and Italy, once she reached those theaters of war. For the rest of her term of service at Fort Oglethorpe, most of Anna Marie’s letters discussed family and friends and further discussions of the social happenings at the base and the dates that she was engaging herself in on a daily basis. She also discussed the ways in which the training

\footnotetext{
${ }^{43}$ Letter Home, Anna Marie Fisher to Stella Fisher, September 4, 1943, 3.

${ }^{44}$ Letter Home, Anna Marie Fisher to Stella Fisher, September 11, 1943, 2.
} 
was shaping up, rigorous, but necessary. She wrote that "My training is very good hard, but it prepares us for any eventuality. We are so tired at the end of a day that we fall into bed early." ${ }^{45}$ This form of rigorous training helped to prepare the women for what would happen once they were in theater and it also gave the women greater training in their specific areas of specialization. Anna Marie remained in Georgia through the end of September and into October, writing her last letter from Fort Oglethorpe on October 11, 1943.

Like many WACs, Anna Marie wished to be transferred overseas. At the beginning of the war, the women of the WAAC had not served overseas in either the Pacific or in Europe and North Africa. Beginning in January 1943, however, women were deployed to overseas theaters of operation. Geoffrey Perret writes that "In January 1943 a carefully chosen company of college-educated WAACs, many fluent in French, were assigned to Eisenhower's headquarters in Algiers. There they operated the switchboard and served as secretaries and translators. In November of that year a group of 60 WACs went to Italy...they were a tremendous boost to morale for an army that was having a miserable time." ${ }^{46}$ Indeed, the presence of the WAC did uplift the spirit of the men who were toiling in theater and their simple presence marked a special moment for the Army. Perret writes that "Nearly 10,000 WACs ultimately served in the ETO...despite the lies and hostility, the lack of recognition and the easily wounded male ego, the WAC won its war: women had a permanent place in the Army." ${ }^{\text {47 }}$ Overseas duty for these women was a competitive assignment and Anna Marie wrote in her letters

\footnotetext{
${ }^{45}$ Letter Home, Anna Marie Fisher to Stella Fisher, September 16, 1943, 4.

${ }^{46}$ Geoffrey Perret, There's A War to be Won: The United States Army in World War II (New York: Ivy Books, 1991), 461.

${ }^{47}$ Ibid., 461.
} 
of being interviewed by WAAC “bigwigs” from Washington and of her requesting to be sent overseas into theater immediately. However, Anna Marie was not accepted for immediate overseas service and this was not appealing to a young woman who had had her eyes set on overseas service. She wrote that "When the Captain said that I had not been recommended because of lack of experience and my youth I nearly fainted. I was brokenhearted about it because every WAC wants to go overseas and so few get the chance...I checked out of the company along with four other Officers who were out for the same reason and went over to Classification to see what kind of assignment they would give me.”48 While Anna Marie was not immediately assigned to overseas service, she would not have to wait long.

In early 1944, following some time at home with her mother, Anna Marie was stationed in North Africa. Unfortunately, none of her letters from this time have survived. From interviews with her brother and pictures that were sent home and preserved, it is clear that Anna Marie enjoyed her time serving in Tunisia and Algeria; she was able to see the ruins of Carthage and the arid plains of the northern Sahara, two things which she definitely would not have been able to experience had it not been for the WAC. A number of the aforementioned photographs from this time did survive. In most of them, Anna Marie is either on camelback or walking through the desert in front of ancient ruins. She is smiling in many of the pictures and seems to be enjoying her service in North Africa; according to her brother, she was quite adept at dealing with the heat (even though she constantly complained about it while stationed at Fort Oglethorpe earlier in her service) and he also said that she was able to travel home once during 1944, though he was stationed elsewhere during her visit. A few letters from before Christmas

\footnotetext{
${ }^{48}$ Letter Home, Anna Marie Fisher to Stella Fisher, October 11, 1943, 1.
} 
1944 were able to stand the test of time; one is written from New York City on December 20 and Anna Marie was about to be sent back overseas, again to Italy. She wished that she could have been in Charleston, especially for the holidays. She wrote about her experiences in North Africa, as well as a one-month tour of Italy that she traveled on with the House Military Affairs Committee, during which she toured much of the war-ravaged peninsula. She wrote that she "saw the spot where our troops made the crossing of the Volturno and Rapido Rivers - all of the bridges were demolished by the retreating Germans and the ones in use now were built by our men as they advanced - all the way to Rome the countryside is scarred by war." ${ }^{49}$

Anna Marie would spend the rest of her time in service stationed on the Italian peninsula; she spent most of her time during the next couple of months struggling to live with the conditions that existed in Italy. To take her mind off of the conditions and off of the situation, Anna Marie had probably the most vibrant social life of her military service. Most of her letters from 1945 are lengthy and are written mainly about dating, socializing in Italy, and the other activities that the women engaged in to occupy their time. These activities that Anna Marie discussed in her letters are microcosms of the greater social change that was occurring in regard to gender conventions. Women had become full soldiers and were achieving new positions every day, dating standards had changed so that married individuals were dating without so much as remorse, and women were working in war-related industries at an unprecedented pace. As far as dating standards were concerned, they definitely were being relaxed in all theaters of service. Beth Bailey and David Farber, in their book The First Strange Place: Race and Sex in World War II Hawaii, write about the dating habits of a woman stationed in Hawaii, habits that were

\footnotetext{
${ }^{49}$ Letter Home, Anna Marie Fisher to Stella Fisher, December 20, 1944, 2.
} 
strikingly similar to Anna Marie's. In discussing the young woman stationed in Hawaii, Rosie Altieri, they write that "On free nights, Altieri went on a whirl of dates. She went out with sailors and marines and men from the Army. She dated officers and enlisted men. Her only rule was that the man who asked her out must be a gentleman, wellbehaved and well-mannered. ${ }^{\text {} 50}$ Many men met these criteria for Ms. Altieri, as they did for Anna Marie. The women of the WAC found that while stationed away from home, the usual standards of dating were relaxed and many more things were acceptable.

On Christmas Day, 1944, Anna Marie wrote her mother a lengthy letter from Italy, expressing her sentiments of sorrow at not being able to be home for Christmas. Similar to her experience while in training at Daytona Beach, however, Anna Marie wrote to her mother that the holidays were not as bad as she thought they might have been. She wrote that the WAC is in a festive holiday spirit, even though many of the women are without family and without good gifts to purchase or to send home. Anna Marie wrote that "We decided to forget about giving gifts as there is nothing to buy over here but still stuff rolls in - our lounge is decorated beautifully and we have a big tree open house will be all day tomorrow...they hung up socks and had hot chocolate - sort of homey and they liked it." ${ }^{\text {"51 }}$ Creating this sort of "homey" atmosphere for the women really helped with morale and also created a situation wherein the women were more comfortable both with the war and with themselves. Another item that helped Anna Marie cope with being away from home once again for the holidays was her upcoming plans and social life. She was planning to travel to Capri in early January and was looking forward to some dates with multiple men over the next couple of days, once

\footnotetext{
${ }^{50}$ Beth Bailey and David Farber, The First Strange Place: Race and Sex in World War II Hawaii (Baltimore: Johns Hopkins University Press, 1992), 85.

${ }^{51}$ Letter Home, Anna Marie Fisher to Stella Fisher, December 25, 1944, 1.
} 
again showing that the dating action was incredibly high, even in theaters of war. Anna Marie's last letter of 1944 is dated the day following Christmas and in it, Anna Marie discussed about her three different dates that she had on Christmas Day and about how her upcoming plans for New Year's were still in the process of developing. Anna Marie was one of the women that Bailey and Farber are describing when they write that "Women who lived near military bases or other strategic areas might well have a surplus of male company. And there were always the civilians, neither too young nor too old."52

The frantic nature of the social life and of the military life was described again by Anna Marie in her letters during January 1945. One of Anna Marie’s good friends also stationed in Italy believed that she was pregnant, which obviously was immediate grounds for dismissal from the WAC, because women with dependents were not allowed to serve in the corps. ${ }^{53}$ While Anna Marie does not clarify what exactly happened to that woman, she does write extensively of the frantic nature of the corps in her 12-page letter. Two weeks later, Anna Marie was able to write once again and apologized for not writing sooner. She wrote that she had been quite busy and that she had acquired a new responsibility, that being "teaching the women classes on operations on the basis of my survey - just finished an hour of it this morning - they will continue for three weeks." ${ }^{54}$ Anna Marie also writes about anticipation for the end of the war. She wrote that she was "awaiting orders - may be a month or more yet and I have no idea what kind of a job I shall get - everything is so indefinite now. The Russians will be in Berlin soon and what happens after that is debatable - we've been so excited over the news.” 55

\footnotetext{
${ }^{52}$ Bailey and Farber, The First Strange Place, 171.

${ }^{53}$ Letter Home, Anna Marie Fisher to Stella Fisher, January 15, 1945, 2.

${ }^{54}$ Letter Home, Anna Marie Fisher to Stella Fisher, January 29, 1945, 1.

${ }^{55}$ Ibid., 2.
} 
The next couple of days in Italy apparently were tough, as Anna Marie began her letter of February 2, 1945 by writing that "I hope that I shall never have to experience another week like that past one - last Sunday part of the aqueduct caved in and we have been without water ever since - taking a bath requires the services of four Italian women who lug the water upstairs from a tank truck and heat it on our wood stove - it is a problem and, while this primitive way of life was fun at first, it is becoming rather disagreeable. ${ }^{56}$ In that same letter, Anna Marie also wrote about the need for nurses and other volunteers that was so strong in the Army at that time. She wrote that "Most of the Army nurses have almost three years over[seas] and they can't go back either because they are so scarce - I do wish that the women at home would answer the plea for more nurses - if they had even the vaguest idea of how badly they are needed, I am sure that they would pitch in and lend a hand - those gals do a miraculous job and deserve the respect and admiration of everyone." ${ }^{\text {,57 }}$ Anna Marie's respect both for the other nurses and for other servicemen and women in general was marked in these letters from Italy and she demonstrated how the manpower of U.S. support personnel and forces, while strong, still needed to be increased.

During February and March of 1945, the Allied forces, mainly the United States, the British, and the Russians, were closing in on the German capital. Though resistance continued in certain areas of Italy until April, the majority of the Italian peninsula was under the control of Allied forces. Those forces were contributing in a rebuilding effort that was coupled with a restructuring of the Italian government. Though some of the duties at this time in Italy were clerical and logistical, U.S. forces were still engaged; in

\footnotetext{
${ }^{56}$ Letter Home, Anna Marie Fisher to Stella Fisher, February 2, 1945, 1.

${ }^{57}$ Ibid., 2.
} 
addition, the war was continuing full force in Germany as the Allied forces attempted to close in on Berlin. Apparently, criticism of the WAC from a few male soldiers had not alleviated by this time, even though it was late in the war and the end seemed to be near. In a February 10 letter, Anna Marie wrote that a friend of hers wrote a letter which "added a last paragraph which made me furious. I quote - 'Be a good little WAC and I'll bring you a tin whistle to pin on your shoulder suit.' - You see how seriously he takes the WAC - and I thought I had him convinced - just finished one to him and I added a few quips of my own.,58 Anna Marie was quick in her letters to defend both her service in the WAC as well as the service of other women and held a sense of pride and accomplishment at serving in the WAC; she was able to dismiss and disregard most of the unsubstantiated criticism and much of the joking.

In that same letter, Anna Marie wrote a lot about wishing to be able to come back home to Charleston. She also wrote about her future plans both for school and when she came home on leave. She wrote, “As for coming home in the near future - I can't tell you anything definite as I don't know myself - am waiting right now to see what will happen to me before I go asking for things - would hate to come home for thirty days and miss a longer stay at home a few months later. ${ }^{59}$ As for future plans, Anna Marie wrote that "if things don't work out as I want them to - after the war I shall attend the University of Wisconsin and study journalism and get a degree - of course, I'll be rather old but I would really love to do it...there's a move afoot to the effect that the WAC will provide education for its veterans if they so desire.”60 Clearly, Anna Marie was looking forward to her return home from service and had made some plans for that return. She

\footnotetext{
${ }^{58}$ Letter Home, Anna Marie Fisher to Stella Fisher, February 10, 1945, 1.

${ }^{59}$ Ibid., 2.

${ }^{60}$ Ibid., 2.
} 
also mentioned attending dances and other social events, in a further effort to meet as many men as possible and to fill her time. She wrote about dating lieutenants and generals over the past couple of weeks and again wrote to her mother that there was nothing wrong with dating married men, again showing how dating standards and gender conventions had shifted during the war, possibly as a result of the frantic stresses of military life and also because service in the military often, to many soldiers, was grim and overbearing.

In her next letter, dated February 13, 1945, Anna Marie wrote that she was "somewhat blue” because of what she labeled as an excessive workload and because one of her closest friends who is in almost every single letter, Smitty, is moping about the WAC camp because she did not receive a pass to go home and see her husband; these displays of sadness and complaining were demoralizing to the women's morale, according to Anna Marie. In regards to the workload, she wrote that "due to the shortage of officers, we pull the evening shifts more often - I just finished the midnight till eight and am now on the seven till midnight - definitely anti-social - but it keeps me out of trouble.”61 Anna Marie’s anti-social phase lasted a short period of time, as she wrote about going on numerous dates and about hopes of a transfer order in her next two letters. Anna Marie hoped to be transferred to France, about which she writes "that fair country was always my first love - Cannes has been turned into a rest camp for our troops and so has Mont St. Michel - someday I must visit that place...the Army has blasted my hopes to bits in its usual fashion - a new circular from the War Department states that a soldier must have twenty-four months service overseas in order to even be eligible - my eighteen

\footnotetext{
${ }^{61}$ Letter Home, Anna Marie Fisher to Stella Fisher, February 13, 1945, 1.
} 
will only be up in April!”62 Service length requirements were subject to change all of the time during World War II, however, it was still demoralizing to some of the men and women when they were so close to the previous cut off and still had to remain in theater because of a change in policy. Anna Marie continued to express her frustration at this subject, writing that "combat troops only have to have a year only we're not classified as such - after what we have been through I feel we deserve that title - being outnumbered twenty to one will give you some idea." ${ }^{, 3}$

The reference that Anna Marie made to being outnumbered twenty to one may have been another contributing factor in why she and other WACs in Italy went on so many dates and why she spent so much time in her letters writing about men. In the six page letter February 17, Anna Marie wrote of dates gone wrong and about how it was OK if they did not work out completely due to the fact that there were so many more men than women serving overseas and that the dating standards had been relaxed on both sides. The women of the WAC were essentially able to date whomever they wanted (or vice versa) and Anna Marie enjoyed that thoroughly. Her work however, does seem to be keeping her at least somewhat busy. She wrote that "I'm assigned to the $15^{\text {th }}$ Air Force Hq. and am one of two WACs working in it...I'm in the communications section doing cryptographic work - vitally interesting and includes the coding and decoding of messages to and from our Hq." ${ }^{64}$ While her work was interesting to her, she also wrote, “must admit that I was terrifically lonesome for female companionship - there are only 3 other WAC officers in town and I don’t see them at all." ${ }^{65}$ Anna Marie does not write

\footnotetext{
${ }^{62}$ Letter Home, Anna Marie Fisher to Stella Fisher, February 17, 1945, 1-2.

${ }^{63}$ Ibid., 2.

${ }^{64}$ Letter Home, Anna Marie Fisher to Stella Fisher, March 5, 1945, 6.

${ }^{65}$ Ibid., 5.
} 
much about the companionship of other women in most of her letters, many of them focus squarely on men, however, her work was keeping her busy so that she did not have an excessive amount of time to worry about female companionship. At previous posts, Anna Marie’s work had been more peripheral, but, at her new post, the duty that she was assigned to learn was one of which "I know absolutely nothing about...and am finding it difficult to learn. It presents a challenge and I shall try my very best to get it - of course, it involves shift work but I don’t mind it too much." ${ }^{, 66}$

As the war in Europe neared its conclusion, like many soldiers in theater, Anna Marie longed for leave or for a permanent return home. She had some worry that she might have been transferred into the Asian theater, something which she longed not to do. She wrote that "if I have to go out to China or India without a leave I fear that my passion for the Army shall suffer - I feel just like an open drawer that someone has been throwing things into for the past two years - need to come home and get all straightened out. My wanderlust is beginning to pale a bit and jouncing about the world is not as exciting as it once was - Charleston will look fine to me." ${ }^{, 67}$ At the same time, although she had concrete plans for her new civilian life, she also worried about adjusting to life in the states. She wrote that "the tension around here is increasing everyday - we all want this war to end quickly and expect it to be before September - golly, I won't know how to conduct myself in America - shall probably talk in pidgin English and forget to pay bills.”68 Sadly, Anna Marie would not ever make that home trip; as the month of March was her last month of service in the WAC.

\footnotetext{
${ }^{66}$ Letter Home, Anna Marie Fisher to Stella Fisher, March 5, $1945,7$.

${ }^{67}$ Letter Home, Anna Marie Fisher to Stella Fisher, March 19, 1945, 2.

${ }^{68}$ Letter Home, Anna Marie Fisher to Stella Fisher, March 23, 1945, 4.
} 
Anna Marie’s letters in her last month express desires to be home and it is clear that Anna Marie and her fellow WACs are ready for the war to end, as were all other soldiers at that time. It would be an exaggeration to say that in her last seven letters she mentioned home more, however, she wrote some things that are quite ironic considering what happened to her in early April. Her letter of March 7, 1945 concerned the transfer orders of her friends and also of her stated intention to apply for permanent transfer station to the United States, as she was growing weary of service overseas. One of her male friends from Fort Devens came to see her at her new station and she was excited to be able to spend time with an "old friend," which she described as a fulfilling time. Anna Marie wrote two letters on March 11 and March 13 in which she asked for civilian clothing items and other things which she needed from home, as well as catching her mother up on the gossip around the WAC base and all of the rumors that were surrounding the completion of the war. Of course these letters also mention dates as usual; the dating scene seems to be going as strong as ever during this time for Anna Marie, again probably because she was so vastly outnumbered by men.

Anna Marie’s letter on March 19 was the first one in which she described the ending of the war as imminent. She wrote to her mother that "I would like to have the last few things that I requested but no more - reason being that the close of the war seems fairly imminent and I don't expect to be in this part of the world long after it is over."69 While Anna Marie would not see the end of the war, her statement in this letter was completely accurate and it serves as a good insight into the lives of the men and women serving in World War II that she was able to accurately predict the end of the war, even though she was not stationed at the center of battle. Concerning her brother, who was

\footnotetext{
${ }^{69}$ Letter Home, Anna Marie Fisher to Stella Fisher, March 19, 1945, 1.
} 
stationed in Great Britain at the time, she wrote, "[I] have a letter ready to go to Steve if I ever get his recent address - will be anxious to hear from him...his coming overseas caused a mild flurry in the Air Corps here - at least ten people gave me information concerning him., ${ }^{, 70}$ Anna Marie was excited to hear information about her brother, who was taking part in bombing missions over Germany at the time.

Anna Marie’s last letter is dated March 28, 1945 and it is a two-page, typed letter that discussed some of her friends and also her new accommodations, which excited her because she was now living with a Captain and a Lieutenant. As usual, she updated her mother on the gossip and the news that was circling around the base and again noted that the end of the war seemed to be closing in. She wrote that "News from the front is amazingly good - all of us are betting furiously on the date that hostilities will cease which brings me to another subject - if the war will be over by the end of June or July I want to wait and come home then - you said that you were glad that I hadn't gone to the

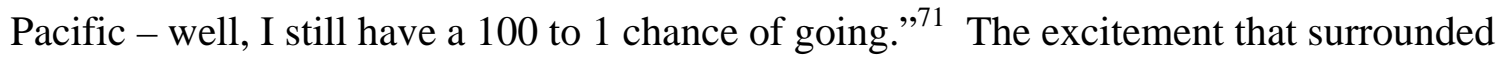
the upcoming end of the war was palpable on the camps and it seemed to be affecting Anna Marie as well, as her last letter is an upbeat, optimistic, and positive one in which she looks forward to coming home. Acting like a daughter, she also wrote her mother that “I do wish I were at home to help you out - sometimes I wonder if I’m not shirking my responsibilities by being in the WAC.,72

Unfortunately, Anna Marie was never able to see how she would conduct herself at home and was never able to pick up the responsibilities that she wrote to her mother that she had "shirked." The family and friends that she had missed so much and had

\footnotetext{
${ }^{70}$ Letter Home, Anna Marie Fisher to Stella Fisher, March 19, 1945, 2.

${ }^{71}$ Letter Home, Anna Marie Fisher to Stella Fisher, March 28, 1945, 2.

${ }^{72}$ Ibid., 2.
} 
mentioned so often in her letters would mourn for her, as, like thousands of other men and women in World War II, Anna Marie did not make it back to the United States. First Lieutenant Anna Marie Fisher was killed in a plane crash on April 20, 1945 in northern Italy. It is unclear what the exact cause of this wreck was; though Anna Marie wrote of bad weather in many of her letters and it could have been that as easily as it could have been a technical or an engine malfunction. Her letters home throughout the war show new insight into the lives of female soldiers serving in the WAC and they also demonstrate the stark changes that occurred in regards to dating and gender conventions during the three and a half years that the WAC were in service. Anna Marie's frantic and full dating life reflected that of many of her fellow servicewomen (and men); it is clear from her letters that she was just a microcosm of the greater picture of American servicewomen in World War II. 


\section{Chapter Four: Staff Sergeant E. Steve Fisher}

During World War II, the United States and Allied forces dropped hundreds of thousands of tons of bombs on Germany in an effort to defeat the Nazi forces. These bombing missions were some of the most treacherous duties assigned to American soldiers during the war in addition to being one of the deadliest. Gerald Linderman writes that "B-17 pilot John Bennett likened a bomber over a German city to a person burdened by two heavy cans of gasoline trying to run rapidly through a dark alley while thugs aimed firecrackers at the open containers." ${ }^{\prime 1}$ B-17 bombers, commonly nicknamed the "Flying Fortress," were used alongside B-24 bombers as the main bombers over Germany during the war. The operating crews of these planes on bombing missions were composed of ten men and uncertainty of returning home was central to every flight. Robin Neillands writes that "B-17 and B-24 crews consisted of ten men. Four of them were trained gunners who operated the ball turret, the tail turret, and the two waist guns and were all enlisted men...two other members of the crew - the wireless operator and the engineer - were also enlisted men, the engineer doubling as the top-turret gunner. The pilot, co-pilot, navigator, and bombardier were officers, and usually college graduates.”2 These missions were both vitally important to Allied success in the war and also caused many of the war's casualties. “Ultimately, 52,000 of America’s 290,000

\footnotetext{
${ }^{1}$ Gerald Linderman, The World Within War: America's Combat Experience in World War II (New York: The Free Press, 1997), 41.

${ }^{2}$ Robin Neillands, The Bomber War: The Allied Air Offensive Against Nazi Germany (Woodstock, New York: The Overlook Press, 2001), 174.
} 
battle deaths were those of air personnel, and the loss rate of bomber crews reached a level exceeded only by the infantry.”3

Anna Marie’s brother, Ernest Steven Fisher, Junior, was one of those men who flew on the bomber crews. Staff Sergeant Fisher was not nearly as prolific of a writer as his sister, so we learn less about his military experience through his letters. Still, Steve’s letters offer some insight into both military training and service overseas. Unlike his sister, Steve lived through the war, received two Purple Hearts, was a Prisoner of War in Germany in late spring, 1945, and left the Army with the ranking of Staff Sergeant. Four years younger than Anna Marie, Steve looked up to his older sister both as a role model and as an example of motivation and accomplishment. Few of Steve's letters from the war have survived; eight survive from his time in training at Jefferson Barracks, Missouri, which span September and October, 1943. In addition, five of his letters from La Harve, France, following his liberation from a German POW camp, have also survived. Oral history, something that was unavailable for Anna Marie, was available for Steve, who passed away on February 19, 2002. His story is not nearly as tragic as Anna Marie's; also, his letters are not nearly as eloquent or lengthy as Anna Marie's. However, they complete the story of a family's experience in World War II and are important in analyzing the differences between WAAC service and Army service during the war.

Ernest Steven Fisher volunteered for the military in 1942 straight out of high school at the age of eighteen. At the time, war propaganda and support actions were in full swing and the United States was fully engaged in the war. Many of Steve's close friends from high school signed up to fight in the war as well; almost all enlisted voluntarily. Anna Marie had been twenty-one when she enlisted in the WAAC, which

\footnotetext{
${ }^{3}$ Linderman, The World Within War, 39.
} 
gave her a few more years of experience than Steve had when he entered the armed forces. Partly due to innate sibling rivalry and partly because he felt a patriotic desire to serve his nation and defeat the horror that was Hitler and the Nazis, Steve was excited to enlist. Though not certain exactly what job he would have in the war and with no specific nor general military training, he enlisted with aspirations to fly planes in the department of the Army that was at that time referred to as the Army Air Corps, now known as the Air Force. Steve felt that it was honorable to sign up for service and he entered because during 1942, enlisting to serve was the correct thing to do for ablebodied young men, thus, Steve enlisted successfully at eighteen after attempting to enlist when he was only seventeen.

Steve completed his basic training in Jefferson Barracks, Missouri during September and October, 1943. Steve described initial Army training in his first letter to his mother, written from Missouri on September 15, 1943. He wrote that "we had camouflage today and I wish you could have seen it. Men in their suits and costumes stood next to us and we didn't even know it. They put on a sham battle for us, there was a machine gun nest and some men on top of a knoll which was well-vegetated." ${ }^{4}$ The troops were quite active during basic training and had rigorous drills all day long, many of which took hours and hours and typified battle situations. Steve wrote that "We had extended order drill which is a squad of 11 to 15 men which are sent out to take a position or on a scouting mission. We have this in the woods with blanks and really enjoy it." ${ }^{5}$ By 1943, the training was realistic and typified battle scenarios much better than previous training. Lee Kennett writes that "Infantrymen fired live ammunition at

\footnotetext{
${ }_{5}^{4}$ Letter Home, Steve Fisher to Stella Fisher, September 15, 1943, 1.

${ }^{5}$ Ibid., 2.
} 
‘buttoned-up’ tanks, and the tanks in turn rolled over infantrymen while they lay crouched in holes. Soldiers crawled through infiltration courses with machine-gun bullets passing thirty inches above them. They moved through 'Nazi' villages, kicking in doors and blazing away at pop-up targets. ${ }^{\circ 6}$ This realistic training was both helpful for preparedness and for simulation.

As far as weapons and similar training was concerned, Steve wrote that "We were issued an M-1 or known as the Garrand, it shoots 8 shots, is semi-automatic, and has swell balance. We have been drilling with them for two days and can handle them pretty well." ${ }^{7}$ Before the war, Steve had experienced only minimal weapons training and he wrote on numerous occasions how difficult the weapons training was for him and that he often had to utilize extra practice opportunities in order to perfect his technique. Considering that he served as a ball-turret gunner during the war, one of the most dangerous and deadliest positions of the war, it is somewhat ironic how little experience that he had with guns, shotguns, rifles, and automatic weapons before the war. With all of the weapons training, there were certain instances of accidents that led to the death of soldiers while training. Some casualties occurred in training because of the need for realism; for example, Kennett writes that “at Fort Gordon, Georgia, for example, in May 1943, when an artillery shell exploded prematurely and killed three men. There were similar accidents elsewhere that spring when infantry practiced advancing with overhead artillery fire. Likewise there were casualties in the parachute exercises.” ${ }^{8}$ Fortunately for Steve, he did not have to deal with these tragic instances, as he mentioned nothing about training deaths in his letters from Jefferson Barracks.

\footnotetext{
${ }^{6}$ Kennett, G.I.: The American Soldier in World War II, 51.

${ }^{7}$ Letter Home, Steve Fisher to Stella Fisher, September 15, 1943, 3.

${ }^{8}$ Kennett, G.I.: The American Soldier in World War II, 51.
} 
Steve described his roommates at barracks in a file-type format. He lived with four other men, Artie Sandbatch, from Madison, Michigan; Bill Thompson from Terre Haute, Indiana; Albert Ziesel from Marblehead, Mississippi; and Walter Wickenhouser, from Chicago. ${ }^{9}$ He described the physical characteristics of these men and also wrote about his initial impressions of each of the men. Overall, he did not seem initially to be happy about the way in which his room situation worked out, however, he later admitted that living with people that one does not like will help to build stronger character. In addition, Jefferson Barracks was filled with men and women from all over the United States and there was no way to assure complacency in all rooming situations. Steve longed in his first couple letters to complete basic training and to fulfill the different requirements that such completion entailed. He wrote that "We have to take a 10 mile hike and they always check your feet to be sure you won't hurt them.”10 He also discussed the Army's testing requirements in that same letter. As he wished to become a pilot, he had to take math, science, and mechanics tests in order to show that he was able to fulfill the requirements for these positions. He wrote, "We had our mechanical aptitude test yesterday and I made a very good grade. We had simple things, we had to assemble a U-Bolt out of two L-shaped bolts, a master screw, and some tops. Then we had to strip a generator then replace the parts. After this we had to sleeve four bolts and wire a light bulb to a double switch."11 Luckily for Steve, he had been interested in mechanics and engines since a young age and was adept at performing these tasks.

Steve's next few letters were a bit longer and it seemed that he was adjusting better to the flow of basic training and that his roommate situation improved, two things

\footnotetext{
${ }^{9}$ Letter Home, Steve Fisher to Stella Fisher, September 17, 1943, 2.

${ }^{10}$ Letter Home, Steve Fisher to Stella Fisher, September 18, 1943, 1-2.

${ }^{11}$ Ibid., 3-4.
} 
which helped him ease the pain of an uncertain situation. His letters ask about friends from home and ask his mother to send food; they also discuss how much he looked forward to receiving his stripes and becoming fully commissioned following the completion of basic. Also, he mentioned some propaganda movies and videos directed and produced by the government that the soldiers had to watch, which the soldiers seemed to enjoy and which seemed to boost morale. Many topics were covered in basic training and Steve was subjected to these topics during his tenure. Kennett writes that in basic, "Six hours were allotted for military courtesy, discipline, and the by-now-familiar Articles of War; ten hours were dedicated to sanitation, first aid, and the inevitable sex hygiene. Three hours were allotted to the protection of military information...There were thirty-six hours of physical training, twenty or more hours of marches and bivouacs, and, finally, four hours of guard duty, twenty of drill, and eighteen of inspection." ${ }^{\text {12 }}$ Steve described some of this training in his letters; he wrote that "Today we began hand to hand fighting and if you think football is rough you should watch this. We are instructed to use all possible means of foul play and this is opposite of what we are used to." ${ }^{\text {13 }}$ He also wrote about training on P-39 Lighting airplanes, which he described as "one of the fastest planes in the world and looks as graceful as swans in flight." ${ }^{14}$ Clearly, Steve was interested in this training and he enjoyed training more as he learned more and more about the airplanes.

On October 1, Steve began his rifle training and also camp training. He wrote that "We had to march to the rifle range which is about 20 miles from camp. We made it in five hours and boy was that a fast pace. We live in shelter halves about the size of a

\footnotetext{
${ }^{12}$ Kennett, G.I.: The American Soldier in World War II, 52.

${ }^{13}$ Letter Home, Steve Fisher to Stella Fisher, September 25, $1943,4$.

${ }^{14}$ Letter Home, Steve Fisher to Stella Fisher, September 21, 1943, 4.
} 
pup tent, eat out of our mess kits and live a rough life.” ${ }^{\text {15 }}$ He described the training and the food that the men ate while they were away from barracks. The entire situation was rough and simulated battle scenarios; Steve remarked in his letters that he had never before experienced anything even remotely like the basic training. Like Anna Marie, Steve also found it necessary to fill a good portion of many of his letters with gossip and news about the various people that are training with him. As a male, Steve had the luxury of knowing a lot more friends from home who were serving in the military and many of his close friends from home were serving simultaneous to him, some also at Jefferson Barracks with him. With all of these things going on, Steve was able to stay upbeat and ended his October 1 letter with two seemingly contradictory sentences. He wrote, "I got a card from Dad and he told me to buck up and keep punching. He talks very morbid. I am having one of the best times of my life!"16 Steve, working to find his niche in the military arena, had to work hard, as did most other soldiers, to complete basic training.

Steve's last two letters from Jefferson Barracks with the $718^{\text {th }}$ Training Group were written on October 2 and on October 13. The October 2 letter was a short one, only the front and back of some Jefferson Barracks stationary in Steve's trademark cursive handwriting. He qualified as a sharpshooter in rifle training, by scoring a 164 on the rifle range test, of which he was proud and for which he received medals, which he sent home to his mother shortly thereafter. Though Steve's time at Jefferson Barracks was brief, he, like Anna Marie, requested all sorts of clothing items, books, and papers which he needed. In his last letter from the states, written on October 13, he apologized for not

\footnotetext{
${ }^{15}$ Letter Home, Steve Fisher to Stella Fisher, October 1, 1943, 1.

${ }^{16}$ Ibid., 4.
} 
writing sooner and wrote about how busy the troops have been. He wrote, "Two days ago we went on bivouac and got back in the middle of the night and fell out for morning check. I began my physical tests that day and just finished tonight. The physical takes all the time for two days. I just got out of that one building long enough to eat and each night we had a movie on why we are fighting." ${ }^{, 17}$ Steve wrote that the classes he took were similar to those that he took in high school, noting that the only real difference was that the stakes were a bit higher in basic. He wrote about map-making class and terrain features class, neither of which he had much trouble completing. Steve completed his basic training on October 20, 1943 and overall, his letters indicate that while he struggled, completion was satisfying and he, like Anna Marie, felt a sense of pride in becoming a full member of the Army.

Following basic training, the men in Steve's unit were flown to Southern Illinois University in Carbondale, Illinois. At this location, from which we wrote no letters but described as flat and boring, the men had Air Corps training for six consecutive weeks. The men had to get acclimated to the various planes and train as gunners and sharpshooters; they were able to receive hands-on practice before going into actual service. The B-17 carried a bomb load between 2,600 and 8,000 pounds and had an altitude ceiling of 35,000 feet alongside a maximum speed of 300 m.p.h. ${ }^{18}$ According to Steve, while learning to deal with these planes was difficult, the men were fed well during training and learned quite a bit. Following Carbondale, Steve was based for a short time in both Midland, Texas and Yuma, Arizona. At each station, the men received further Air Corps training and each day, Steve said that he was becoming more and more

\footnotetext{
${ }^{17}$ Letter Home, Steve Fisher to Stella Fisher, October 13, 1943, 2.

${ }^{18}$ Neillands, The Bomber War, 175.
} 
excited about what he was getting the chance to do. After flying to Lincoln, Nebraska in February 1944, Steve was assigned to the B-17 Flying Fortress as the ball-turret gunner, which was a dangerous but exciting position for him. Before traveling overseas however, the men had to transport their equipment and set up their planes for service. These activities were to take place in Maine, but engine trouble and plane maintenance problems kept the men from leaving at their scheduled time and Steve went to New York. Steve traveled to Britain aboard the Aquatania, which was in fact a sister ship to the famous Lusitania. Following a six day journey across the Atlantic, Steve and his unit landed in Liverpool, England in October 1944.

The job of ball-turret gunner was one of the deadliest jobs of the war. Thousands of ball-turret gunners were killed among the 52,000 airmen that were killed during the war. In the bombing raids over Germany which Steve participated in, 9,937 Americans were killed. ${ }^{19}$ Gerald Linderman writes that "In April 1944 [months before Steve entered the ETO], the Army Air Corps’ commanding officer, Henry ‘Hap’ Arnold, warned the Joint Chiefs that 'the massive likelihood of death was beginning to affect his crews - the loss rate was currently $85 \%$ of the total force over a tour of twenty-five sorties.' The historian Michael Sherry calculated that, overall, only 27 percent of air crews were able to complete twenty-five raids over Germany.”20 These bombing raids clearly were difficult for the men involved and many of the men became stressed, however, the bombings continued for months and months; to ease this stress, the men sometimes looked for women with which to fill their time. John Costello writes that "Lieutenant Ted Binder, one of the 9,937 American airmen who perished in the great Allied bomber

\footnotetext{
${ }^{19}$ Costello, Virtue Under Fire, 92.

${ }^{20}$ Linderman, The World Within War, 39.
} 
offensives over Germany, discovered when his turn came as mail censor just how promiscuous air crews were. He was shocked at their boasts in letters to their pals of sexual adventures with English girls, while at the same time assuring their wives or sweethearts back in the States that they were their only love." ${ }^{21}$ Similar to what happened among the WACs, the men serving in Europe also adhered to greatly relaxed dating standards. This helped the men to deal with the great possibility of being killed while bombing. Probably due in large part to the difficulties of war, "after more than a year abroad, whether they were married or single, most American soldiers had thrown restraint to the winds.,22

The main airfield that Steve used while in England, Kimbolton Air Force Base, was also used by tens of thousands of other soldiers and was base camp and starting point for many of the bombing runs that the Allied troops flew into Germany. Steve's particular mission, which was often to fly into Germany, bomb whichever specific target was to be attacked that evening or that day, and then successfully fly back to Kimbolton, was part of the job according to him, as difficult as it may have seemed. Steve said that the bombing experience was trying but unique; sometimes the men would encounter little opposition while other times the B-17s were barraged with opposition fire. The B-17s themselves were behemoths for the time and generally cruised around 35,000 feet and had a range of over 4,400 miles. Steve recalled that the inside cabin was quite cold, usually around forty-five degrees below zero and that to protect the men, electrically heated suits were worn in an effort to make sure that hypothermia did not set in on any men. One of Steve's two Purple Hearts was earned when his electrically heated suit,

\footnotetext{
${ }^{21}$ Costello, Virtue Under Fire, 92.

${ }^{22}$ Ibid., 97.
} 
which was designed for a specific usage but was utilized by the Army for various tasks, was blown up. As a result, Steve received extensive frostbite wounds and thus received a Purple Heart. Steve felt that he did not deserve that medal since he did not lose a limb, however, he was proud of his accomplishments.

On the $20^{\text {th }}$ mission of Steve's B-17 bombing group, every military man's nightmare occurred. While on a bombing run north of Berlin, Germany in March 1945, the B-17 was shot down by German forces and the entire crew of the aircraft was forced to parachute out and thus, were separated. None of the men had any idea whereas to the location of the others and Steve recalls that he simply ran for cover. He landed near a forest and ran for five days toward what he believed were the front lines. Holding minimal provisions and walking around behind enemy lines, Steve had to be quite careful with his actions and decisions while attempting to get back to Allied lines. He said that he ran at night and slept in crevices and other hiding spots during the day, sometimes stealing potatoes from farmers simply to survive, as he had no food provisions. In fact, the only things that he was able to take with him were a compass, a map, sugar pills, and a rubber canteen. Apparently, Steve made it to within twelve miles of American forces but was captured while walking at dusk. He was sent by train to Lubeck, Germany, the location of one of German's many Prisoner of War camps. He recalled that the prison huts held 20-25 prisoners and the prisoners in the camps were from all different Allied nationalities. The men slept on straw mats upon wooden floors and the conditions of the camp were absolutely terrible, with lice coming out at night and rodents prevalent all around. The physical toll on Steve after this was enormous - he went twenty days without a shower or without brushing his teeth and was a prisoner for over thirty days. In 
addition, due to lack of food, Steve's weight dropped from 172 to 126 pounds. Finally though, to the relief of all the soldiers, the British and Americans liberated the camp in early May, $1945 .^{23}$

Steve was lucky that he was shot down so late in the war, as many other American and Allied soldiers were not able to escape the Prisoner of War camps alive. Prisoner of War camps were horrible places and during World War II, the atrocities were especially vulgar. Michael Adams writes that these atrocities were "part of the moral unreason of war. This conduct is often condemned but the torture and killing had the same rationale as the dropping of the atom bombs...men in all armies shot prisoners because they were too exhausted to tend to them properly." ${ }^{24}$ Steve and the prisoners that were incarcerated with him received little food just as Adams describes, however, they were able to survive and due to the short length of time remaining in the war when they were captured, many of them were liberated with only relatively minor physical injuries and discomfort. Tens of thousands of G.I.s were imprisoned at some point during their service; nowhere was the incarceration a pleasant experience and Germany was one of the worst, especially early in the war.

Following liberation from the Prisoner of War camp, the Americans were sent to Camp Lucky Strike, which was located in La Harve, France. From this location, Steve wrote five letters home and was incredibly excited to have made it to a place where the American troops were and where he no longer was a prisoner subjected to awful conditions. In addition, his mother, who for the past two months had been desperately trying to find out what had happened to her two children, who were missing

\footnotetext{
${ }^{23}$ Oral Interview, Steve Fisher, interview conducted by Brook Anne Berger, May 2000.

${ }^{24}$ Michael C.C. Adams, The Best War Ever: America and World War II (Baltimore: The Johns Hopkins University Press, 1994), 111.
} 
simultaneously, was overcome with relief when she found out that she had not lost both of her children in the war. In his first letter, dated May $15^{\text {th }}$, Steve wrote that he was "Still trying my darndest to get home but it seems a few thousand other G.I.’s have the same idea. I have managed to get to the coast of France and am sweating out on a boat. I should reach the U.S.A. by April $1^{\text {st }}$, but don't count on it. As usual everything is messed up and thousands are waiting ahead of us." ${ }^{25}$ The air of expectation and anticipation was running high at Camp Lucky Strike, as none of the soldiers knew exactly what would happen to them. As thousands and thousands of soldiers were waiting to go home, the confusion was understandable. Lee Kennett writes that “In May 1945, the Army's strength stood at 8,300,000 men; by the end of the year half that number had returned to civilian life...to the men waiting overseas, the Army seemed to be taking forever. It was the last great opportunity for the G.I. to gripe, and he made the most of it." ${ }^{\text {26 }}$ Kennett also describes the tone of the camps during the time that the men were waiting in these camps, “The determination to 'get the job done’ had been the glue that held the G.I. Army together; now that the job was done, the glue was beginning to dissolve. Cohesion and discipline both suffered."27

The men who were in the tent cities waiting to be sent home had no idea, of course, that the war would be completely over within a few months; that is part of the reason that Steve thought that he might not be home for almost a year. He was able to get home much sooner than that, but in the interim, he wrote letters home that described the experience. As far as food was concerned, he wrote on May 17 that "We are eating better every day, they started us off on a diet and worked up to a real meal - still a lot of fellas

\footnotetext{
${ }^{25}$ Letter Home, V-Mail, Steve Fisher to Stella Fisher, May 15, 1945, 1.

${ }^{26}$ Kennett, G.I.: The American Soldier in World War II, 224.

${ }^{27}$ Ibid., 224.
} 
that had been prisoners for a great length of time (eating black bread and water soup) have been sick. A young, short prisoner like yours truly hits the chow line twice a meal!"28 He also wrote in this letter that the food that they were being served was fantastic and included such items as steak, lamb, and great pasta. He even wrote that the Army was providing all of the men with cigarettes and asks why the Army could not have been doing that the whole time. In describing this situation, Kennett alludes to the cigarettes and the chaos that existed in these tent cities. "Soldiers in Europe were processed through tent cities near ports of embarkation - places such as Camp Herbert Tareyton and other ‘cigarette camps' set up around Le Havre. Processing for embarkation could take two or three days and would include a physical (with the inevitable short arm), exchanging money, and the recording of souvenirs - one ship left Le Havre carrying five thousand troops and twenty thousand souvenir weapons." ${ }^{29}$ The men still in Europe at this time were not nearly as strictly regulated as they were earlier, as the end of the war in Europe had occurred; though, some soldiers feared being sent to the Pacific theater.

Steve’s next letter home is dated May 27, 1945 and discussed how the plans have once again changed and how he found out that the other members of his plane that were shot down had all already been sent home and that all but one had been sent through Le Havre, though he had not seen any of them. This news excited Steve and he wrote to his mother that he could not wait to see all of those people, though he still did not no exactly when he would be able to come home. As far as day to day life, Steve wrote that "We had a physical today, got shots, new clothes, checked records, and got back in the G.I.

\footnotetext{
${ }^{28}$ Letter Home, Steve Fisher to Stella Fisher, May 17, 1945, 2.

${ }^{29}$ Kennett, G.I.: The American Soldier in World War II, 225-6.
} 
Army officially! We are all ready to ship but 'Sammy' tells us he just can’t spare the boats right now. We have no right to gripe though, the boys in the South Pacific need 'em worse than we do." ${ }^{30}$ He again wrote about how the soldiers should not gripe, while he himself somewhat griped, in his next letter. He wrote again of being excited to come home and also wrote that "we've been told we no longer have our priority [to be shipped home]! At first we were important enough to rate with the wounded - now we come first after 4-F's and Germans. We really don't have any right to gripe though, we eat like kings, have no formations, play ball all day, and visit local towns anytime we like...how's that for an Army camp!”31 It seems that the conditions were quite relaxed at Camp Lucky Strike and that life for the men was not nearly as bad as it was during the war itself.

For the troops still stationed in Europe, it was clear that despite better conditions, no amount of relaxation and free time could equate to being home; Steve himself was adamant about coming home. He wrote that "We should leave this camp around the $10^{\text {th }}$ or $15^{\text {th }}$ of this month! At the same time though we must take into consideration the fact that transportation is overtaxed, and around ten or fifteen thousand men are ahead of me. In other words, it's safe to say 'I'll be home for Christmas.”32 In the same letter, he also wrote that "We have been processed finally and placed in packets according to our home state. We have a tent full of West Virginia 'ridge runners' from every city you can think of - even from some I've never heard of." ${ }^{33}$ This diverse experience proved to be a short one for Staff Sergeant Fisher, as he wrote on June 6 that the men were coming home and

\footnotetext{
${ }^{30}$ Letter Home, Steve Fisher to Stella Fisher, May 27, 1945, 2.

${ }^{31}$ Letter Home, Steve Fisher to Stella Fisher, June 2, 1945, 1.

${ }^{32}$ Ibid., 1.

${ }^{33}$ Ibid., 2.
} 
that he hoped he was able to beat the letter itself home, but was unsure as to whether or not that would happen. His boat ended up sailing into Boston, Massachusetts on June 14, 1945 (ten months earlier than he had initially thought that he would be home) and Steve recalled that he was thrilled to be home, though he was obviously devastated at what happened to his sister. After arriving in Boston, Steve's unit went back to Camp Meade, Maryland where the soldiers had to go through final physicals. After one week of physicals, dental work, and overall stagnation, the men were supposed to be sent to another Air Corps grouping in San Antonio, Texas, however, this did not occur and the men received a 90-day furlough. During these 90 days, the United States dropped atomic bombs on two Japanese cities, Hiroshima and Nagasaki, each of which were completely devastated by the powerful bombs. These bombings finally caused the Japanese to surrender and as a result, Steve and tens of thousands of other G.I.'s were discharged from service.

Following his discharge, Steve took advantage of the provisions of the G.I. Bill and attended West Virginia University, graduating in 1949 with a degree in Business. He went on to a successful real estate career in Charleston, West Virginia and lived until February 19, 2002. Many of the men who had served in the Air Corps (which became the Air Force at the end of the war) suffered combat fatigue and had difficulty readjusting to civilian life, however, Steve was not one of them. Steve was captured physically but not emotionally and overall, he was able to come out without any long-term negative effects from his POW experience. Steve was lucky in that his entire crew survived and reunited once back in America almost every year; in addition, he was mentally unscathed and had a greater appreciation for life due to his experiences. Another result of his 
service, which was a result for many of the men who served, was that Steve became a born-again Christian and looked at his war experiences as leading him in that direction. Steve recalled that during World War II, all of the men worked together cohesively for what he labeled as the "freedom of humanity" and also for the good of their nation. Steve said that looking back, the experience was enlightening and that he was able to learn all that he needed to know about the world and about others from his experiences in the war. 


\section{Chapter Five: Conclusion}

The brother and sister whose stories are told throughout the previous eighty-four pages are just a microcosm of the U.S. military in general and the men and women who served in World War II. A mother had both of her children fighting in the war and each served valiantly for their nation, one dying in the line of service. The letters of both Steve and Anna Marie show the modern reader how the men and women in service were able to cope with the stresses of war. In addition, Anna Marie's letters are indicative of the way in which dating standards were relaxed and gender conventions changed during World War II. The service of the WAC was a watershed moment in more ways than one. Also, "military service had a powerful liberating effect on many American women, which was summed-up by one WAAC who told the researchers, 'I feel competent for the first time and independent. It is a good feeling to be able to take care of yourself." ${ }^{1}$ These feelings were shared by many of the veterans of the WAC and were crucial for women as they worked toward the culmination of their struggle for equal rights that climaxed a generation later.

Anna Marie and Steve both were decent letter writers and each filled their letters with as much war news as they could, however, what was most important from these letters was the gossip, the stories, and the insights into military training. These three things give the researcher a real feel for exactly what the mentality of the women was during the war. Also, they tell of such specific details as what items were included in their diets, the sorts of training that they were given in training camp, the way that they felt about their fellow soldiers and their superior officers, and the general mentality of the

\footnotetext{
${ }^{1}$ Costello, Virtue Under Fire, 54.
} 
men and women who were serving. Reading these letters sixty years later places the modern reader back into World War II - back into Daytona Beach for WAAC training and back into Camp Lucky Strike for an insight into life following V-E Day. These letters from contemporary soldiers are the best possible primary sources for the war, whether the soldiers are male or female.

The spring of 1945 must have been an extremely difficult time for Stella Fisher, as both of her children were simultaneously missing in action. Anna Marie’s “plane crashed into a mountain on April 20, 1945, 10 days after her brother's plane shot down and he was reported missing." ${ }^{2}$ At this same time, Stella's father was dying of cancer, creating a trying situation for her. Luckily for Stella's sanity, Staff Sergeant Fisher was recovered and quickly wrote home to let his mother know that all was alright. He left the service decorated as "EAME w/2 bronze star Good Conduct Purple Heart ETO w/2 battle stars." ${ }^{3}$ These awards, while important to Steve, were not able to make up for the fact that his only sibling was killed in combat. Survival in the face of battle is crucial in understanding the importance of the mentality of the men and women serving in World War II and death while serving for your nation in the face of battle were crucial as well. The uncertainty that surrounds war in general is a prevailing theme in both Steve and Anna Marie’s letters, both while they were in service in America and in Europe. All in all, the strength of the men and women who fought in combat and served the Allied cause during World War II will never be forgotten and archiving letters and mementos is a perfect way to view the effect of the war on families. In the case of First Lieutenant Anna Marie Fisher and Staff Sergeant Steve Fisher, the letters also offer an insight into

\footnotetext{
${ }^{2}$ Charleston Daily Mail, November 11, 1991.

${ }^{3}$ Official Army Document, October 27, 1945.
} 
the lives of soldiers serving overseas and insight into the shifting gender conventions that came about as a result of the WAC service in World War II. 


\section{Bibliography and Works Cited}

Adams, Michael C.C. The Best War Ever: America and World War II. Baltimore: The Johns Hopkins University Press, 1994.

Allen, Ann. “The News Media and the Women’s Army Auxiliary Corps: Protagonists For a Cause.” Military Affairs 50 (April 1986): 77-83.

Anderson, Karen. Wartime Women: Sex Roles, Family Relations, and the Status of Women During World War II. Westport, Connecticut: Greenwood Press, 1981.

Bailey, Beth and Farber, David. The First Strange Place: Race and Sex in World War II Hawaii. Baltimore: The Johns Hopkins University Press, 1992.

Braybon, Gail and Summerfield, Penny. Out of the Cage: Women’s Experiences in Two World Wars. London: Pandora Press, 1987.

Campbell, D’Ann. “Women in Combat: The World War II Experience in the United States, Great Britain, Germany, and the Soviet Union.” The Journal of Military History 57 (April 1993): 301-323.

Campbell, D’Ann. “Women in Uniform: The World War II Experiment.” Military Affairs 51 (July 1987): 137-139.

Charleston Daily Mail. “Son’s Return Home From War Eased Mother’s Pain.” November 11, 1991.

Clark, Blake. “Ladies of the Army.” Readers Digest, May 1943, 85-88.

Costello, John. Virtue Under Fire: How World War II Changed Our Social and Sexual Attitudes. Boston: Little, Brown, and Company, 1985.

Fisher, Anna Marie. Letters Home. December 15, 1942 through March 28, 1945.

Fisher, Anna Marie. Women are in it Too. Contained in war possessions of E. Steve 
Fisher, Jr. Circa 1943.

Fisher, E. Steve. Letters Home. September 15, 1943 through June 6, 1945.

Fisher, E. Steve. Oral History. May 2000. Interview conducted by Brook Berger.

Fussell, Paul. Wartime: Understanding and Behavior in the Second World War. New York: Oxford University Press, 1989.

Hartmann, Susan M. The Home Front and Beyond: American Women in the 1940s. Boston: Twayne Publishers, 1982.

Hauser, Ernest O. “Those Wonderful G.I. Jane’s.” Saturday Evening Post, 9 September 1944, 27.

Honey, Maureen. Creating Rosie the Riveter: Class, Gender, and Propaganda During World War II. Amherst, Massachusetts: The University of Massachusetts Press, 1984.

Kennett, Lee. G.I.: The American Soldier in World War II. Norman, Oklahoma: The University of Oklahoma Press, 1997.

Linderman, Gerald. The World Within War: America’s Combat Experience in World War II. New York: The Free Press, 1997.

Litoff, Judy Barrett and Smith, David C., eds. American Women in a World at War: Contemporary Accounts From World War II. Wilmington, Delaware: Scholarly Resources, Inc., 1997.

May, Elaine Tyler. “Rosie the Riveter Gets Married.” Contained in The War in American Culture: Society and Consciousness During World War II. Lewis A. Erenberg and Susan E. Hirsch, eds. Chicago: The University of Chicago Press, 1996. 
Meyer, Leisa D. Creating G.I. Jane: Sexuality and Power in the Women’s Army Corps During World War II. New York: Columbia University Press, 1996.

Meyer, Leisa D. “The Lesbian Threat: Within the World War II Women’s Army

Corps.” Contained in Women and War in the Twentieth Century: Enlisted With Or Without Consent. Nicole Ann Dombrowski, ed. New York: Garland Publishing, Inc., 1999.

Neillands, Robin. The Bomber War: The Allied Air Offensive Against Nazi Germany. Woodstock, New York: The Overlook Press, 2001.

Paton-Walsh, Margaret. Our War Too: American Women Against the Axis. Lawrence, Kansas: The University Press of Kansas, 2002.

Perret, Geoffrey. There’s A War to be Won: The United States Army in World War II. New York: Ivy Books, 1991.

“They Work Too Hard.” Time, 24 August 1942, 59.

“WAACS and WAVES.” Life, 15 March 1943, 72.

"Waac to Wac.” Newsweek, 12 July 1943, 22.

“WAAC: U.S. Women Troop to Enlist in Army’s First All-Female Force.” Life, 8 June 1942, 26.

Weatherford, Doris. History of Women in America: American Women and World War II. New York: Facts on File, Inc., 1990.

Women’s Army Auxiliary Corps. Enlistment Postcard. Circa Fall 1942.

Yellin, Emily. Our Mother's War: American Women at Home and at the Front During World War II. New York: Free Press, 2004. 